\title{
SELECTION OF CONSTITUENT MATERIALS FOR ASPHALT MIXTURES OF NOISE-REDUCING ASPHALT PAVEMENTS
}

\section{AUDRIUS VAITKUS, OVIDIJUS ŠERNAS*, VIKTORAS VOROBJOVAS, JUDITA GRAŽULYTE்}

Road Research Institute, Vilnius Gediminas Technical University, Vilnius, Lithuania

Received 18 February 2019; accepted 1 April 2019

\begin{abstract}
Road traffic noise is a widespread problem, especially in the densely populated cities of Europe. Exposure to high levels of (traffic) noise leads to health problems, such as stress, sleep disturbance and even heart diseases. Noise-reducing asphalt pavements are more frequently developed and selected as a first noise abatement solution. Performance of noise-reducing asphalt pavement depends on the composition and properties of asphalt mixture components, and pavement properties such as layer thickness, voids in pavement, texture. Design of asphalt mixture for the noise-reducing asphalt pavements is even more complicated for severe and cold climate regions where significant temperature fluctuations and many of frost-thaw cycles occur. Thus, the balance between mechanical and acoustical durability depends on the proper selection of asphalt mixture components. Components of these asphalt mixtures have primarily to be tested to determine their physical and mechanical properties. The main aim of this research is to evaluate properties of local aggregates, bituminous binders, and regarding test results, select the most suitable materials for the design of high-quality, durable asphalt mixtures
\end{abstract}

* Corresponding author. E-mail: ovidijus.sernas@vgtu.lt

Audrius Vaitkus (ORCID ID 0000-0001-5103-9747)

Ovidijus Šernas (ORCID ID 0000-0002-0019-4242)

Viktoras Vorobjovas (ORCID ID 0000-0001-9420-0668)

Judita Gražulytė (ORCID ID 0000-0001-6502-9400)

Copyright (C) 2019 The Author(s). Published by RTU Press

This is an Open Access article distributed under the terms of the Creative Commons Attribution License (http://creativecommons.org/licenses/by/4.0/), which permits unrestricted use,

distribution, and reproduction in any medium, provided the original author and source are credited. 
for noise-reducing asphalt pavements. The research showed that Granite A is the most suitable aggregate for the design of asphalt mixtures for noise-reducing asphalt pavement. Short-term and particularly long-term ageing of polymer modified bituminous binder PMB 45/80-65 and PMB 25/55-60 decreases the number of aromatics and increases the amount of resins. Based on Multiple Stress Creep and Recovery test results, it is assumed that all bituminous binders selected for research are suitable for the asphalt mixture design of noise-reducing asphalt pavement in terms of resistance to rutting. However, considering all tests results, bituminous binder PMB 45/80-65 (1) showed the best performance and was the most suitable for the asphalt mixture design of noise-reducing asphalt pavement.

Keywords: asphalt mixture, bituminous binder, noise reduction, noise-reducing asphalt pavement, physical and mechanical properties, road-building materials.

\section{Introduction}

Road traffic noise is a widespread problem, especially in the densely populated cities of Europe. Exposure to high levels of (traffic) noise leads to health problems, such as stress, sleep disturbance and even heart diseases (Li, Wen, Feng, \& Wei, 2016; Sakhaeifar, Banihashemrad, Liao, \& Waller, 2017; Vuye, Bergiers, \& Vanhooreweder, 2016). World Health Organization (WHO) estimated that disability-adjusted life-years lost from environmental noise are 61000 years for ischaemic heart disease, 45000 years for cognitive impairment of children, 903000 years for sleep disturbance, 22000 years for tinnitus and 587000 years for annoyance in the European Union. Sleep disturbance and annoyance mostly related to road traffic noise; embody the main burden of environmental noise (Kim, 2011; Vuye, Bergiers, \& Vanhooreweder, 2016). There are different sources of noise emissions in a vehicle such as an engine, transmission, cooling fan, exhaust, injection system, and tyrepavement interaction. Between these different sources of noise in a vehicle, tyre-pavement interaction noise has become an increasingly important issue in densely congested urban settings near busy highways (Ejsmont, Goubert, Ronowski, \& Świeczko-Żurek, 2016; Sakhaeifar, Banihashemrad, Liao, \& Waller, 2017). Road traffic noise is mostly dependent on driving speed. Moreover, different travelling vehicle noise sources dominate at different speeds, for example vehicle propulsion noise dominates at low speeds (below $40 \mathrm{~km} / \mathrm{h}$ ), tyre/road noise dominates at the speed range from $40 \mathrm{~km} / \mathrm{h}$ to $100 \mathrm{~km} / \mathrm{h}$ and noise due to vehicle aerodynamics dominates at very high speeds (above than $120 \mathrm{~km} / \mathrm{h}$ ) (Rasmussen, Bernhard, Sandberg, \& Mun, 2007). Noise barriers and noise walls are the most popular noise
Judita Gražulytè

Selection

of Constituent

Materials

for Asphalt Mixtures of Noise-Reducing

Asphalt Pavements 
abatement solutions in the road sector, but at the same time, their construction and maintenance is expensive, complicated and in some cases even impossible due to various restrictions. Alternatively, noise-reducing asphalt pavements are more frequently developed and selected as a primary noise reducing solution (Bendtsen, Kragh, \& Nielsen, 2008). Different type of asphalt mixtures are used for noise-reducing asphalt pavements - optimised stone mastic asphalt (SMA) and asphalt concrete (AC), porous asphalt (PA), very thin layers asphalt concrete (BBTM), ultra-thin asphalt concrete (AUTL) and crumb rubber modified asphalt concrete. For noise-reducing asphalt pavements also poroelastic road surface (PERS) are used, containing aggregates, sand, rubber granules from recycled tyres and binder of polyurethane (Ejsmont, Świeczko-Żurek, Owczarzak, Sommer, \& Ronowski, 2018). The most promising techniques of pavement surface characteristics optimisation for noise reduction are texture optimisation (SMA, AC, BBTM, and AUTL) and increase of porosity. All these mixtures can be defined as asphalt mixtures of noise-reducing asphalt pavement, but noise-reducing asphalt pavement performance depends on the composition and properties of asphalt mixture components and pavement properties. The following properties and their values of the asphalt mixture for noise-reducing pavement components in recipes have to be changed and adjusted to optimise the noise reduction (Miljkovic, 2012; Miljković \& Radenberg, 2012; Ripke, Andersen, Bendtsen, \& Sandberg, 2005):

- maximum aggregate size;

- the shape of the aggregate (cubic, flat, round);

- the distribution of the size of aggregate and filler;

- the percentage of bituminous binder and modifier type;

- the built-in air void;

- the thickness of porous asphalt pavement layers;

- the amount of rubber or other elastic material.

Optimisation of asphalt mixtures for tyre/road noise reduction mainly depends on the potential application area of these mixtures where it will be used, under what traffic and what climate conditions. Design of the asphalt mixtures for noise-reducing asphalt pavement is even more complicated for severe and cold climate regions where significant temperature fluctuations and many of frost-thaw cycles occur. In such cases, it is essential to take the design with sufficient durability and resistance to climate conditions. A national research project NOPE, which is aimed at the design of these asphalt mixtures for severe climate conditions were started in December 2017 in Lithuania (Vaitkus, Andriejauskas, Gražulytė, Šernas, Vorobjovas, \& Kleizienè, 2018). 
This paper presents the second stage of this project aiming, to a selection of the best suitable materials for the design of asphalt mixture for noise-reducing asphalt pavement. This research aims to evaluate properties of local aggregates, bituminous binder, and regarding test results, select the most suitable materials for the design of asphalt mixture for noise reducing asphalt pavement. Apart from usual test methods and specifications, test methods were applied to determine such bituminous binder properties as creep compliance and critical low temperature.

\section{Requirements for constituent materials and mixture composition of asphalt mixture for noise-reducing asphalt pavement}

Asphalt mixture consists of about 95\% aggregate mixture $(90 \%$ aggregate and $5 \%$ filler), and about $5 \%$ bituminous binder (Snilsberg, Myran, Uthus, \& Aurstad, 2008). Asphalt mixtures of noise-reducing asphalt pavement contain the same components as standard asphalt mixtures, the main difference comparing to usual asphalt mixtures higher amount of air voids that is achieved by coarser gradation (Alberts 0'Malley, Byrne, Faber, \& Roebben, 2017). The SMA of noise-reducing asphalt pavement has a smaller maximum particle size generally about $5 \mathrm{~mm}$ or $6 \mathrm{~mm}$. Content of voids is between $5 \%$ and $10 \%$, much higher than typical SMA (PIARC Technical Committee, 2013). Since asphalt mixtures of noise-reducing asphalt pavement are used for wearing course in the high traffic level roads or streets, aggregates must meet the highest requirements for physical and mechanical properties: high resistance to fragmentation and polishing, shape of the particles must be cubical, surface of the particles must be $100 \%$ crushed (PIARC Technical Committee, 2013; Sandberg, Kragh, Goubert, Bendtsen, Bergiers, Biligiri, Karlsson, Nielsen, Olesen, \& Vansteenkiste, 2011). Additionally, these parameters are crucial for noise-reducing asphalt pavement: Los Angeles (LA) abrasion (below 30\%), fractured faces (above 90\% for particles with 2 faces, $100 \%$ for particles with 1 face), flat and elongated particles (below 5\% and below 20\% (ratios 5:1 and 3:1 respectively)) (Alvarez Martin, Estakhri, Button, Glover, \& Jung, 2006). The choice of the aggregate shall also consider binder-aggregate affinity - good adhesion between aggregate and binder prevents ravelling and therefore, improves the durability (Sandberg, Kragh, Goubert, Bendtsen, Bergiers, Biligiri, Karlsson, Nielsen, Olesen, \& Vansteenkiste, 2011). However, sufficient binder-aggregate adhesion can be ensured using 
adhesion additives. These characteristics of the aggregate will result in the durability of the surface texture, skid resistance and noise reduction (PIARC Technical Committee, 2013; Sandberg, Kragh, Goubert, Bendtsen, Bergiers, Biligiri, Karlsson, Nielsen, Olesen, \& Vansteenkiste, 2011). The most critical parameter about the climate or weather is the ability to resist degradation caused by cycles of freezing and thawing when the aggregates are in wet conditions (Sandberg, Kragh, Goubert, Bendtsen, Bergiers, Biligiri, Karlsson, Nielsen, Olesen, \& Vansteenkiste, 2011). Regarding the fact that Lithuanian climate conditions are characterised as severe conditions for road infrastructure (60-80 frost-thaw cycles annually), aggregates resistance to freezing/thawing is very significant (Andriejauskas, Vorobjovas, \& Cygas, 2016). Research showed that granite is the most resistant to polishing and fragmentation aggregate in Lithuania ((Polished Stone Value (PSV) 56-57; Los Angeles coefficient (LA) 10-15)). This aggregate even after an increased number of freezing and thawing cycles, keeps the same mechanical properties. Dolomite is less resistant to mechanical and environmental impact comparing to granite (Vorobjovas, Šernas, Žilionienè, Šneideraitienè, \& Filotenkovas, 2017). By literature analysis, the main requirements for the aggregates are LA, water absorption, Flakiness Index (FI), Shape Index (SI), resistance to freezing and thawing.

In the asphalt mixture, the most climate-sensitive component typically is the bituminous binder. The temperature in the wearing course of the asphalt pavement structures in Lithuania changes during the year from $-18.88{ }^{\circ} \mathrm{C}$ to $+50.73{ }^{\circ} \mathrm{C}$; thus, the difference is almost $70{ }^{\circ} \mathrm{C}$ (Žiliūtè, Motiejūnas, Kleizienè, Gribulis, \& Kravcovas, 2016). The viscoelastic properties of the bituminous binder depend on the temperature and the traffic load - during a hot period, the bituminous binder is like a viscous liquid and permanent deformation or rutting of the asphalt mixture occurs. As the temperature drops below zero, the critical property of the bituminous binder in the mixture is elastic stiffness. Bituminous binder becomes brittle at low temperatures, and when the critical temperature is reached, transverse cracks appear on the asphalt pavement (Sandberg, Kragh, Goubert, Bendtsen, Bergiers, Biligiri, Karlsson, Nielsen, Olesen, \& Vansteenkiste, 2011). Sandberg \& Ejsmont (2002) recommended avoiding a bituminous binder that gives a very stiff surface (tentatively). Various additives and modifiers can be used such as styrene-butadiene-styrene (SBS), styrene-butadiene rubber (SBR) and crumb rubber (CR) to improve properties and performance of asphalt mixtures of noise-reducing asphalt pavement. If bitumen is modified appropriately, it will prevent short-term ravelling that is caused by the shear forces between the tyre and road interfaces (Vaitkus Andriejauskas, Gražulytė, Šernas, 
Vorobjovas, \& Kleizienė, 2018). Polymer-modified bituminous binder offers essential advantages as compared to unmodified bitumen for resistance to ravelling, binder drainage and durability (PIARC Technical Committee, 2013; Sandberg, Kragh, Goubert, Bendtsen, Bergiers, Biligiri, Karlsson, Nielsen, Olesen, \& Vansteenkiste, 2011). The properties of crumb rubber modified bitumen mostly depend on the neat bitumen, modification process parameters (temperature, duration, and pressure) and amount of crumb rubber. Neat bitumen modification with crumb rubber improve modified bitumen properties related to high-temperature performance (softening point, elasticity, viscosity) and reduce sensitivity to ageing and low-temperature impact (McNally, 2011). However, crumb rubber modified bituminous binder not provides lower noise due to modification with crumb rubber.

In Europe, bitumen is classified by penetration grade system by standards EN 12591:2009 Bitumen and Bituminous Binders - Specifications for Paving Grade Bitumens and EN 14023:2010 Bitumen and Bituminous Binders - Specification Framework for Polymer Modified Bitumens. The correct choice of polymer modified bitumen from EN 14023:2010 depends on the geographic area (climatic conditions, including minimum and maximum temperatures) and the traffic conditions (Sandberg, Kragh, Goubert, Bendtsen, Bergiers, Biligiri, Karlsson, Nielsen, Olesen, \& Vansteenkiste, 2011). However, the main properties of polymer modified bituminous binder by standard EN 14023:2010 are penetration, softening point, elastic recovery, resistance to short-term ageing. These properties mainly are used to check whether polymer modified bituminous binder complies with European requirements for particular polymer modified bituminous binder type, but these properties do not ensure adequate performance for bituminous binder and asphalt mixture in specific climate and traffic conditions.

In most states of USA, bituminous binders are still classified by the Performance Grade classification system by standard AASHTO M 320:2010 Standard Specification for Performance-Graded Asphalt Binder. However, almost all states started implementation procedures or have already implemented a classification system by standard AASHTO M 332:2014 Specification for Performance-Graded Asphalt Binder Using Multiple Stress Creep Recovery (MSCR) test. Performance grade classification system was updated because of a parameter $G^{*} / \sin \delta$ was found to be inadequate for characterising different modified bituminous binders - it is suitable only for unmodified bitumen. Regarding this fact, modified bituminous binder parameter $G^{*} / \sin \delta$ does not correlate well to asphalt mixture performance in high temperature (Anderson, 2014; Hanz, 2015; Syslo, 2016).
Selection

of Constituent

Materials

for Asphalt Mixtures

of Noise-Reducing

Asphalt Pavements 

system used in the USA and EU

\begin{tabular}{|c|c|c|c|c|c|c|c|c|c|}
\hline \multirow[b]{3}{*}{ Property } & \multicolumn{9}{|c|}{ Bituminious binder } \\
\hline & \multicolumn{3}{|c|}{ Original } & \multicolumn{3}{|c|}{ RTFOT } & \multicolumn{3}{|c|}{ RTFOT+PAV } \\
\hline & 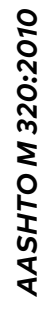 & 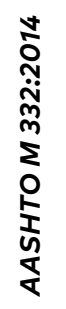 & 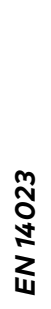 & 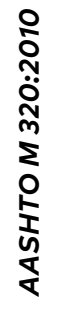 & 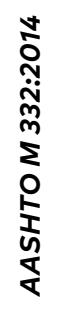 & 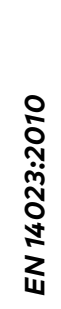 & 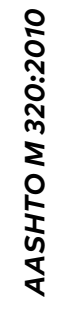 & 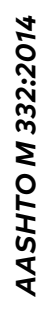 & 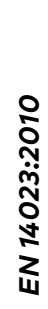 \\
\hline Flash point & + & + & + & - & - & - & - & - & - \\
\hline Rotational viscosity & + & + & - & - & - & - & - & - & - \\
\hline Rutting parameter $G^{*} / \sin \delta$ & + & + & - & + & - & - & - & - & - \\
\hline $\begin{array}{l}\text { Non-recoverable creep } \\
\text { compliance } J_{n r 3.2}\end{array}$ & - & - & - & - & + & - & - & - & - \\
\hline $\begin{array}{l}\text { Difference in non-recoverable creep } \\
\text { compliance } J_{n, \text { diff }}\end{array}$ & - & - & - & - & + & - & - & - & - \\
\hline Fatigue parameter $G \cdot \sin \delta$ & - & - & - & - & - & - & + & + & - \\
\hline Stiffness $S$ and $m$ - value & - & - & - & - & - & - & + & + & - \\
\hline Failure strain $\varepsilon_{f}$ & - & - & - & - & - & - & + & - & - \\
\hline Penetration & - & - & + & - & - & - & - & - & - \\
\hline Softening point & - & - & + & - & - & - & - & - & - \\
\hline Cohesion & - & - & + & - & - & - & - & - & - \\
\hline Change of mass & - & - & - & - & - & + & - & - & - \\
\hline Retained penetration & - & - & - & - & - & + & - & - & - \\
\hline Increase in softening point & - & - & - & - & - & + & - & - & - \\
\hline Decrease in softening point & - & - & - & - & - & + & - & - & - \\
\hline Elastic recovery & - & - & + & - & - & + & - & - & - \\
\hline Fraas breaking point & - & - & + & - & - & - & - & - & - \\
\hline Storage stability & - & - & + & - & - & + & - & - & - \\
\hline Plasticity range & - & - & + & - & - & - & - & - & - \\
\hline
\end{tabular}

Note: + required property; - not required property. 
A summary of classification systems of bituminous binders by standards AASHTO M 320:2010, AASHTO M 332:2014 and EN 14023:2010 are presented in Table 1.

Standard AASHTO M 332:2014 classification system advantages comparing to standard AASHTO M 320 classification system (Anderson, 2014; Hanz, 2015; Syslo, 2016) are:

- uses the Dynamic Shear Rheometer (DSR) for faster results;

- for both unmodified and modified binders;

- identifies the presence of an elastomeric modifier;

- excellent correlation with rutting;

- high-stress level engages polymer network.

By standard AASHTO M 332:2014, the main parameters are nonrecoverable creep compliance $\left(J_{n r 3.2}\right)$ and recovery (\%Recovery) that addresses to rutting during the hot season. Required $J_{n r 3.2}$ and \%Recovery values at set test temperature depend on traffic level - severe traffic conditions require lower $J_{n r 3.2}$ value and higher \%Recovery value (Table 2).

A map showing the level of standards AASHTO M 320:2010 and AASHTO $M$ 322:2014 implementation level in each state is given in Figure 1. As given in Figure 1 presents the most states have implemented standard AASHTO M 320:2010 specifications, but even 11 states have already implemented standard AASHTO M 332:2014 requirements.

Each region has different climate and traffic conditions, different origin aggregates and uses bituminous binders from different suppliers with different requirements. Because it is necessary to evaluate the suitability of each region materials used for asphalt mixture design. Proper asphalt mixture components selection ensures good asphalt mixture performance in terms of components. However, asphalt mixture performance depends also on the proportions of components.
Selection

of Constituent

Materials

for Asphalt Mixtures of Noise-Reducing Asphalt Pavements

Table 2. The main requirements for bituminous binder high-temperature performance by AASHTO M 332:2014

\begin{tabular}{|c|c|c|c|}
\hline Symbol (letter) & Traffic Level & $J_{n r 3.2}$ value & \%Recovery \\
\hline Standard (S) & below 3 million ESALs & below $4.5 \mathrm{kPa}^{-1}$ & - \\
\hline Heavy $(H)$ & above 3 million ESALs & below $2.0 \mathrm{kPa}^{-1}$ & no less than $30 \%$ \\
\hline Very Heavy (V) & above 10 million ESALs & below $1.0 \mathrm{kPa}^{-1}$ & no less than $55 \%$ \\
\hline Extreme (E) & $\begin{array}{l}\text { above } 30 \text { million ESALs } \\
\text { and standing traffic }\end{array}$ & below $0.5 \mathrm{kPa}^{-1}$ & no less than $75 \%$ \\
\hline
\end{tabular}



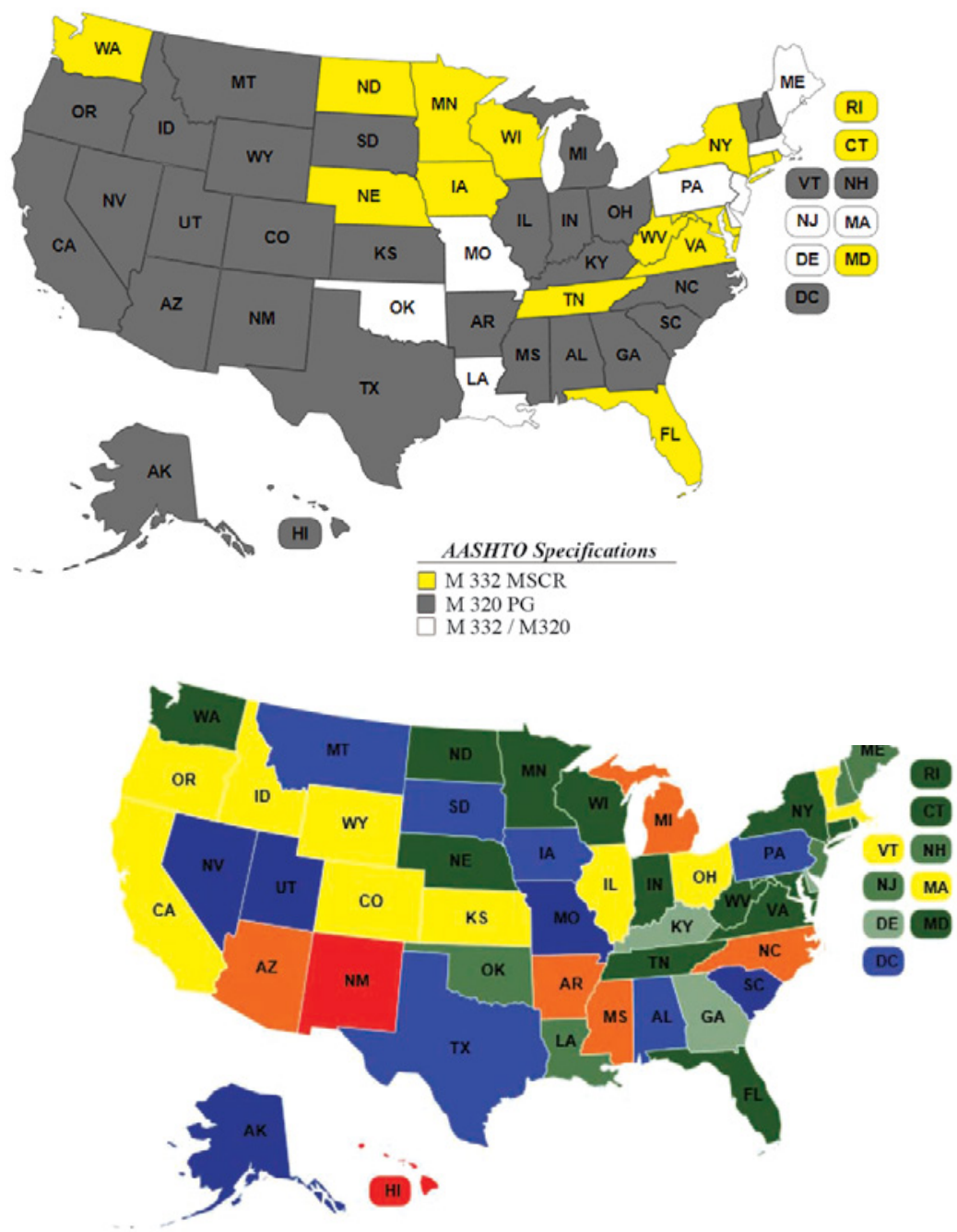

State Color Key

Full Implementation

Full Implementation Modified Grades Only

Planned Full Implementation (12 months)

Partial Implementation

Planned Partial Implementation (12 months)

Considering Impelemtation (No Time Frame)

Testing/Evaluation

No Activity

To Be Posted Soon
State Hover Color Key

INAUPG (Northeast Asphalt User Producer Group) SEAUPG (Southeastern Asphalt User Producer Group) NCAUPG (North Central Asphalt User Producer Group)

RMAUPG (Rocky Mountain Asphalt User Producer Group)

I7 PCCAS (Pacific Coast Conference on Asphalt Specifications)

source: http://www.asphaltinstitute.org/engineering/specification-databases/ us-state-binder-specifications/

Figure 1. Map of implementation the AASHTO Performance Grade classification system in the USA 


\section{Experimental Research}

\subsection{Materials}

Dolomite and crushed gravel aggregates were selected from quarries in Lithuania. Granite in Lithuania is imported from foreign countries as Ukraine, Norway, Belarus and processes imported material into broad and narrow fractions. Granite aggregates for the experimental research were selected from different three granite aggregate manufacturers in Lithuania. In the first stage of experimental research, three different type aggregates (granite, dolomite and crushed gravel) separated fractions $(2 / 5,5 / 8$ and $8 / 11)$ were tested and analysed. In the second stage, four bituminous binders were analysed: two different type bituminous binders PMB 25/55-60 and PMB 45/80-65 from two different manufacturers were tested and analysed. The types of bituminous binders were selected by literature analysis and market supply - all selected bituminous binders comply with literature recommendations and market supply. These bituminous binders were marked as PMB 45/80-65 (1) and PMB 25/55-60(3) from one manufacturer, and from other - PMB 45/80-65 (2) and PMB 25/55-60 (4). Bituminous binders after Rolling Thin-Film Oven Test (RTFOT) were marked as 1-A, 2-A, 3-A and 4-A, while bituminous binders after RTFOT+PAV (Pressure Ageing Vessel) were marked as 1-B, 2-B, 3-B and 4-B respectively.

\subsection{Methods}

An experimental plan (Figure 2) to find out the most suitable aggregate and bitumen for the design of asphalt mixture for noisereducing asphalt pavement were made based on literature review and Lithuanian requirements. The experimental research consists of two stages. The first stage was committed to finding out the most suitable aggregate for asphalt mixture of noise-reducing asphalt pavement and the second - to find out the most suitable bituminous binder for asphalt mixture of noise-reducing asphalt pavement. For each of them, the physical and mechanical properties, which are listed below, were determined:

- aggregate particle size distribution by standard LST EN 9331:2012 Tests for Geometrical Properties of Aggregates - Part 1: Determination of Particle Size Distribution - Sieving Method;

- oven-dried particle density and water absorption by standard LST EN 1097-6:2013 Tests for Mechanical and Physical Properties of Aggregates - Part 6: Determination of Particle Density and Water Absorption;
Selection

of Constituent

Materials

for Asphalt Mixtures

of Noise-Reducing

Asphalt Pavements 
- Flakiness Index (FI) by standard LST EN 933-3:2012 Tests for Geometrical Properties of Aggregates - Part 3: Determination of Particle Shape - Flakiness Index;

- Shape Index (SI) by standard LST EN 933-4:2008 Tests for Geometrical Properties of Aggregates - Part 4: Determination of Particle Shape - Shape Index;

- percentage of crushed and broken surfaces by standard LST EN 933-5:2002/A1:2005 Tests for Geometrical Properties of Aggregates - Part 5: Determination of Percentage of Crushed and Broken Surfaces in Coarse Aggregate Particles;

- resistance to fragmentation (LA) by standard LST EN 1097-2:2010 Tests for Mechanical and Physical Properties of Aggregates - Part 2: Methods for the Determination of Resistance to Fragmentation.

Three specimens were prepared and tested to determine each of the listed properties.

In the experimental research were analysed four bituminous binders. Physical and mechanical properties and test methods determined for each of them are these:

- penetration by standard LST EN 1426:2015 Bitumen and Bituminous Binders - Determination of Needle Penetration;

- softening point by standard LST EN 1427:2015 Bitumen and Bituminous Binders - Determination of the Softening Point - Ring and Ball Method;

- elastic recovery by standard LST EN 13398:2018 Bitumen and Bituminous Binders - Determination of the Elastic Recovery of Modified Bitumen;

- short term ageing by standard LST EN 12607-1:2015 Bitumen and Bituminous Binders - Determination of the Resistance to Hardening under Influence of Heat and Air - Part 1: RTFOT Method;

- long term ageing by standard LST EN 14769:2012 Accelerated LongTerm Ageing Conditioning by a Pressure Ageing Vessel (PAV);

- critical high temperature by standard AASHTO T 315 Standard Method of Test for Determining the Rheological Properties of Asphalt Binder Using a Dynamic Shear Rheometer (DSR);

- non-recoverable creep compliance $\left(J_{n r}\right)$ and recovery (\%Recovery) by standard AASHTO TP 70 Standard Method of Test for Multiple Stress Creep Recovery (MSCR) Test of Asphalt Binder Using a Dynamic Shear Rheometer (DSR);

- critical low temperature by standard AASHTO Determining the Low-Temperature Rheological Properties of Asphalt Binder Using a Dynamic Shear Rheometer (DSR) (draft version) prepared by Farrar, Sui, Salmans, \& Qin (2015). 


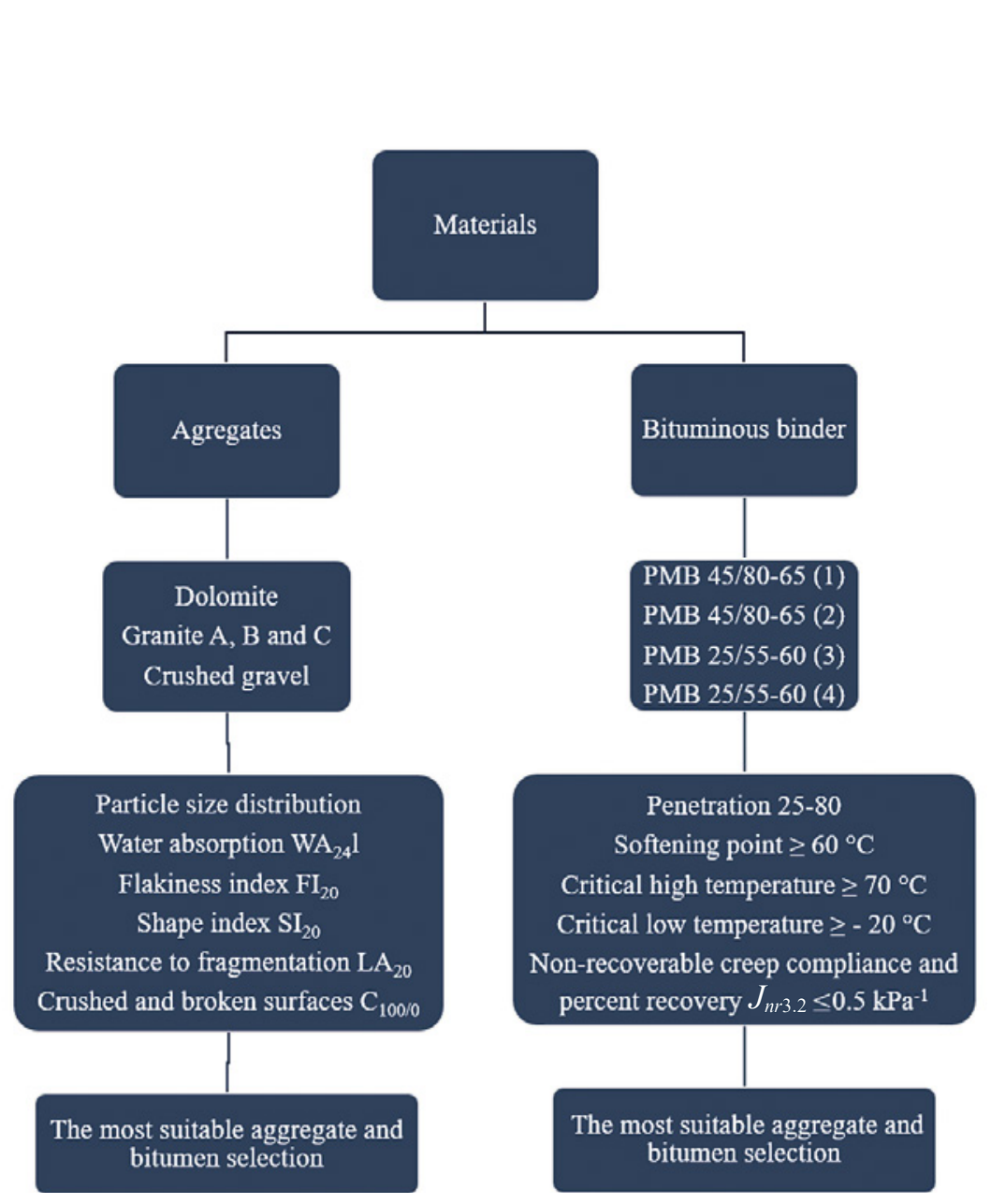

Figure 2. Experimental plan

The conventional physical properties of bituminous binders, including penetration at $25{ }^{\circ} \mathrm{C}$, softening point and elastic recovery at $25{ }^{\circ} \mathrm{C}$ was tested by standards EN 1426:2015, EN 1427:2015 and EN 13398:2018 respectively.

Rheological properties of the bituminous binders were measured with a dynamic shear rheometer (Anton Paar Co. Ltd. of Austria MCR301) in a parallel plate configuration. Rheological tests were performed under controlled strain condition. The key rheological parameters obtained from the DSR were complex modulus $\left(G^{*}\right)$ and the phase angle $(\delta)$. Complex modulus is defined as the ratio calculated by dividing the absolute value of the peak-to-peak shear stress $(\tau)$ by the absolute value of the peak-to-peak shear strain $(\gamma)$. The $\delta$ is the angle in radians between a sinusoidal applied strain and the resultant sinusoidal stress in a controlled-strain testing mode. Temperature 
sweeps (from $76^{\circ} \mathrm{C}$ to $88^{\circ} \mathrm{C}$ ) were applied at a fixed frequency of $1.6 \mathrm{~Hz}$ for determination of critical high-temperature for short-term aged bituminous binders. The plate used for temperature sweep test was $25 \mathrm{~mm}$ in diameter, and the gap among the parallel plates was $1 \mathrm{~mm}$.

Multi Stress Creep and Recovery tests of short-term and long-term aged bituminous binders were performed at $60^{\circ} \mathrm{C}$ temperature using ten cycles at two stress levels: $0.1 \mathrm{kPa}$ and $3.2 \mathrm{kPa}$.

Critical low temperature for unmodified bituminous binders was determined by performing temperature sweeps (from $-12{ }^{\circ} \mathrm{C}$ to $-24{ }^{\circ} \mathrm{C}$ at the range of frequencies from $0.01 \mathrm{~Hz}$ to $10 \mathrm{~Hz}$ ). Master curve of storage shear modulus that is the complex shear modulus multiplied by the cosine of the phase angle expressed in degrees, and by interconverting this master curve to relaxation modulus was created. Critical low temperature is a higher (less negative) temperature at which relaxation modulus or slope of relaxation modulus at a loading time of $60 \mathrm{~s}$ is equal to $143 \mathrm{MPa}$ and -0.28 , respectively. The diameter of the parallel plates used at low-temperature tests was $4 \mathrm{~mm}$, and the gap among the parallel plates was $1.75 \mathrm{~mm}$. During testing, one of the parallel plates oscillated for the other at pre-selected frequencies and rotational deformation amplitudes within linear viscoelastic range.

Thin-layer chromatography and flame ionisation detection (TLCFID) technique was used to separate bituminous binder into saturated aromatics, resins, and asphaltenes. Bituminous binder solutions were prepared in toluene, and $1 \mu \mathrm{l}$ of the sample solution was spotted on Chromarods. In this research, the TLC-FID was conducted using Iatroscan MK-6s analyser. The samples were dissolved in toluene with a concentration of $1 \%(\mathrm{w} / \mathrm{v})$. After Chromarods were cleaned and activated, $1 \mu \mathrm{L}$ of sample solution was spotted on each Chromarod using a spotter. The separation was performed using a three-stage process. The first stage was in $\mathrm{n}$-heptane $(100 \%)$, the second stage in toluene $(100 \%)$, and the last stage was in dichloromethane/methanol $(95 / 5$ by volume). Finally, the Chromarods were scanned in the TLC-FID analyser. For each sample, 10 Chromarods were tested, and the average value of the seven readings was taken as a result.

\section{Results and discussion}

\subsection{Aggregates}

The physical and mechanical properties of the aggregates, which were analysed, are presented in Tables 3-4 and Figures 3-5. Error bars in the graphs represent the minimum and maximum values. 
Table 3. Results of gradation

\begin{tabular}{lcccccccccc}
\hline \multicolumn{1}{c}{ Aggregate } & \multicolumn{1}{c}{ Passing, \% } \\
\cline { 2 - 10 } & $\mathbf{0 . 0 6 3}$ & $\mathbf{0 . 1 2 5}$ & $\mathbf{0 . 2 5}$ & $\mathbf{0 . 5}$ & $\mathbf{1}$ & $\mathbf{2}$ & $\mathbf{5 . 6}$ & $\mathbf{8}$ & $\mathbf{1 1 . 2}$ & $\mathbf{1 6 . 0}$ \\
\hline Granite A (2/5) & 1.4 & 1.6 & 1.7 & 1.7 & 1.8 & 3.6 & 96.2 & 100.0 & 100.0 & 100.0 \\
Granite B (2/5) & 1.5 & 1.5 & 1.5 & 1.5 & 1.5 & 3.6 & 95.7 & 100.0 & 100.0 & 100.0 \\
Granite C (2/5) & 0.2 & 0.2 & 0.2 & 0.2 & 0.3 & 3.7 & 90.9 & 100.0 & 100.0 & 100.0 \\
Dolomite (2/5) & 0.5 & 0.6 & 0.7 & 0.7 & 0.9 & 7.5 & 92.5 & 100.0 & 100.0 & 100.0 \\
Crushed gravel (2/5) & 0.2 & 0.2 & 0.2 & 0.2 & 0.2 & 0.6 & 92.2 & 100.0 & 100.0 & 100.0 \\
Granite A (5/8) & 0.8 & 1.0 & 1.2 & 1.3 & 1.5 & 1.8 & 9.8 & 94.5 & 100.0 & 100.0 \\
Granite B (5/8) & 0.7 & 0.9 & 1.0 & 1.0 & 1.0 & 1.0 & 15.9 & 89.2 & 100.0 & 100.0 \\
Granite C (5/8) & 0.1 & 0.1 & 0.1 & 0.1 & 0.1 & 0.1 & 5.8 & 83.2 & 100.0 & 100.0 \\
Dolomite (5/8) & 0.2 & 0.2 & 0.2 & 0.2 & 0.2 & 0.2 & 11.8 & 92.2 & 100.0 & 100.0 \\
Crushed gravel (5/8) & 0.9 & 1.0 & 1.2 & 1.3 & 1.7 & 3.9 & 30 & 96.0 & 100.0 & 100.0 \\
Granite A (8/11) & 0.6 & 1.0 & 1.0 & 0.7 & 0.7 & 0.7 & 0.8 & 11.5 & 96.8 & 100.0 \\
Granite B (8/11) & 0.2 & 0.2 & 0.2 & 0.2 & 0.2 & 0.2 & 0.3 & 7.0 & 80.1 & 100.0 \\
Granite C (8/11) & 0.1 & 0.2 & 0.2 & 0.2 & 0.2 & 0.2 & 0.2 & 5.1 & 74.7 & 100.0 \\
Dolomite (8/11) & 0.2 & 0.2 & 0.2 & 0.2 & 0.2 & 0.3 & 0.3 & 9.6 & 93.2 & 100.0 \\
Crushed gravel (8/11) & 0.3 & 0.5 & 0.5 & 0.5 & 0.5 & 0.6 & 1.1 & 12.1 & 88.2 & 100.0 \\
\hline & & & & & & & & & \\
\hline
\end{tabular}

Determination of the particle size distribution shows that Granite $\mathrm{B}$ and Granite $\mathrm{C}$ fractions 5/8 and 8/11 do not comply with the requirements for aggregates given in national technical normative document because passing through the $5 \mathrm{~mm}$ and $8 \mathrm{~mm}$ sieves respectively is outside the $90-99 \%$ limit (Table 3). Therefore, Granite $\mathrm{B}$ and Granite $\mathrm{C}$ were rejected from the experiment, and a further test was not performed on these materials. It was observed that Dolomite is coarser than Granite A. Regarding the gradation results, Granite A, Dolomite and Crushed gravel are suitable for the design of asphalt mixture for noise-reducing asphalt pavement. Consequently, further aggregate tests were performed with these aggregates.

The test results of aggregates shape properties showed that FI and SI generally depend on aggregates origin and fraction. However, compared to the same origin aggregates (Granite A, Granite B and Granite C), the results of shape properties were unequal. Flakiness Index of Granite $A$ fraction 2/5 is 1.4 times less than Granite B and C. fraction 5/8 - 3 times less than Granite B and fraction 8/11 - 2.7 times less than Granite B and Granite C. Similar tendencies were observed analysing results of SI. 


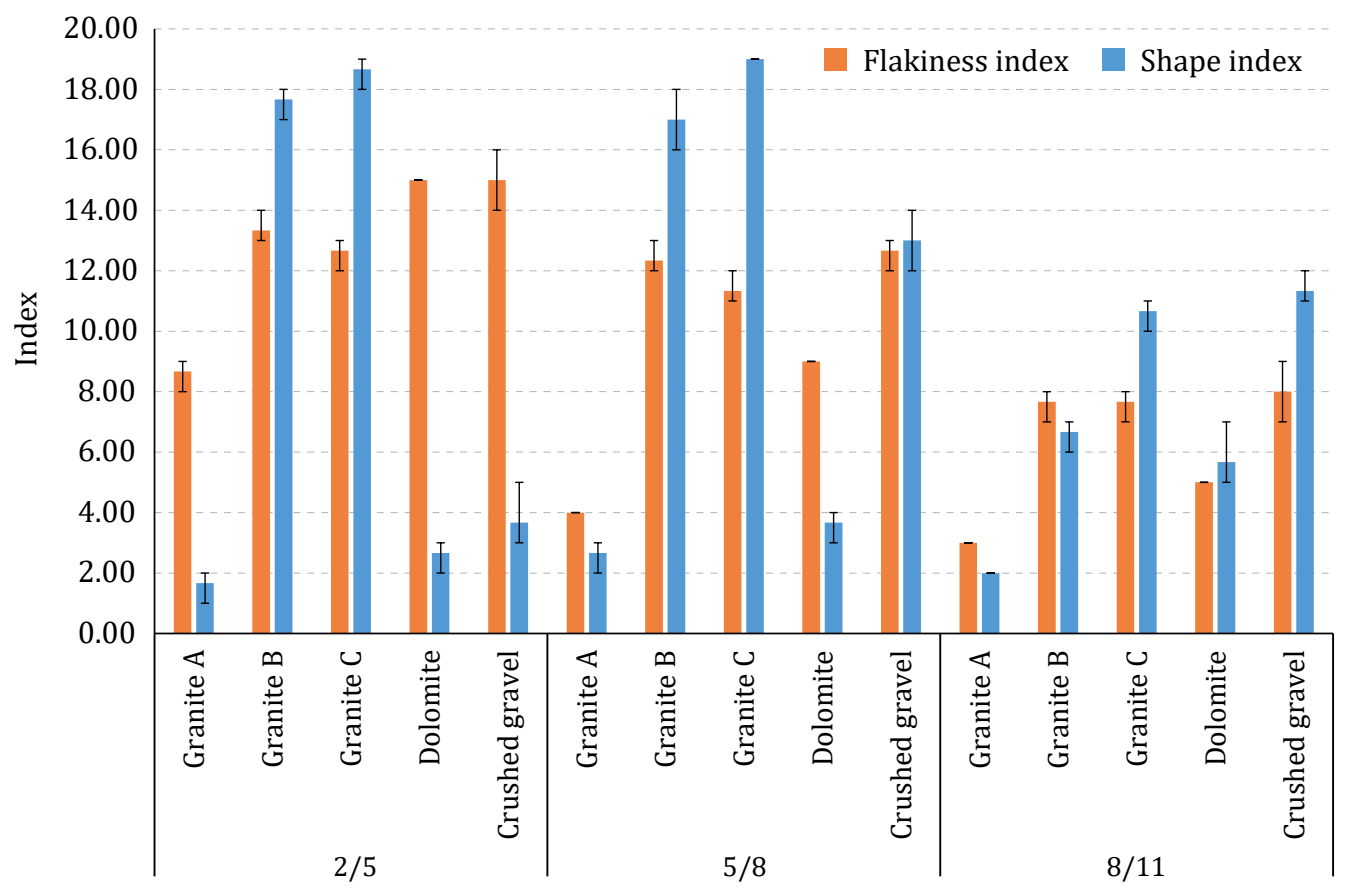

Figure 3. Test results of Flakiness and Shape Indexes of aggregates

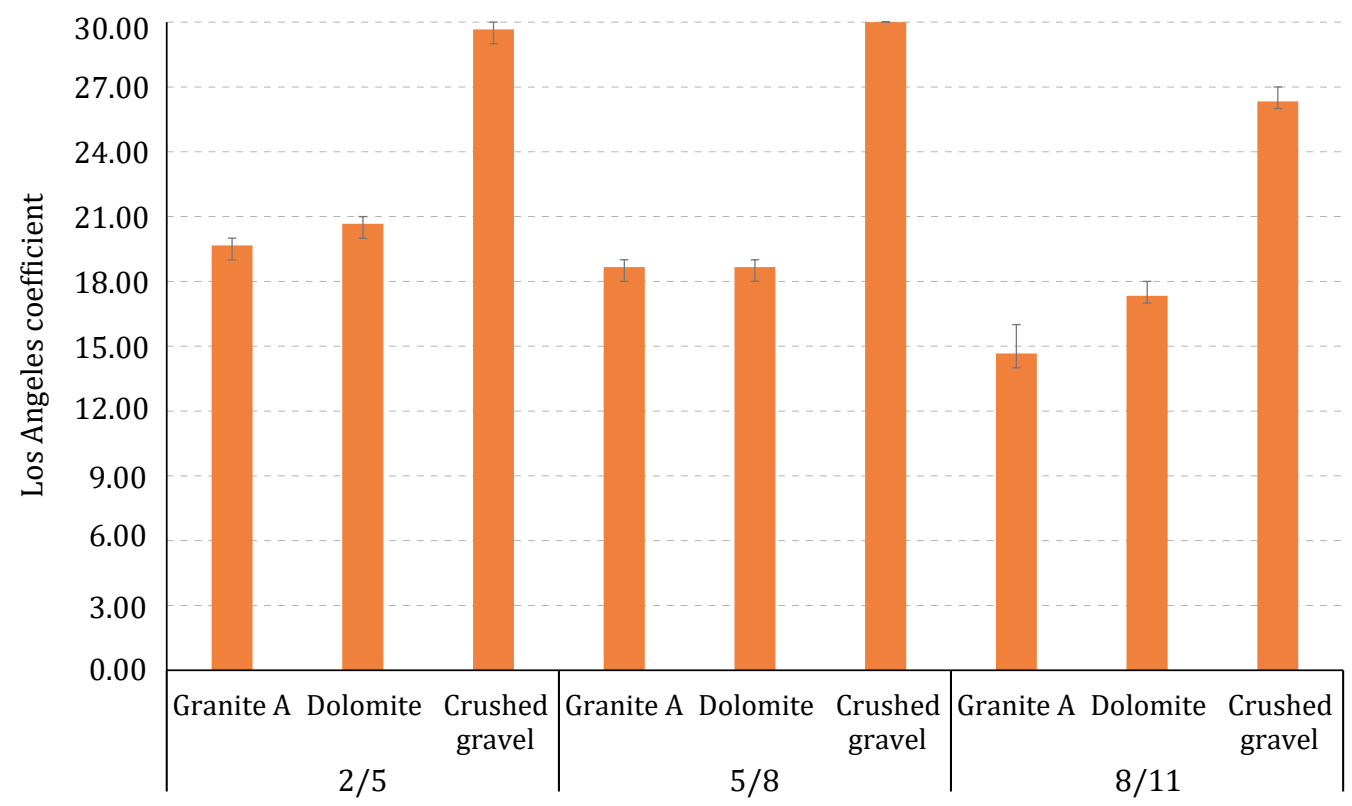

Figure 4. Test Result of the Los Angeles coefficient of aggregates 
Despite these facts, FI and SI values of all tested aggregates are less than 20 , so these aggregates meet the highest requirements in terms of shape properties. By results of the test and the fact that uniformly shaped cubical aggregates are necessary to design asphalt mixture for noisereducing asphalt pavement, Granite A is assumed as the most suitable aggregate for the design of asphalt mixture for noise-reducing asphalt pavement in terms of FI and SI.

The test results of aggregates mechanical properties (Figure 4) showed that both Granite A and Dolomite $L A$ is below 20 and these aggregates are suitable for the asphalt mixture of noise-reducing asphalt pavement in terms of mechanical properties. However, Crushed gravel showed lower resistance to fragmentation and did not meet requirements in terms of mechanical properties.

The analysis of water absorption test results (Figure 5) showed that Granite A is the most resistant to freezing and thawing - Granite A is $1.3 \%$ more resistant to freezing and thawing than Dolomite and $1.4 \%$ than Crushed gravel. Comparing to the results of Dolomite and Crushed gravel, it is stated that the results are equal.
Selection

of Constituent

Materials

for Asphalt Mixtures

of Noise-Reducing

Asphalt Pavements

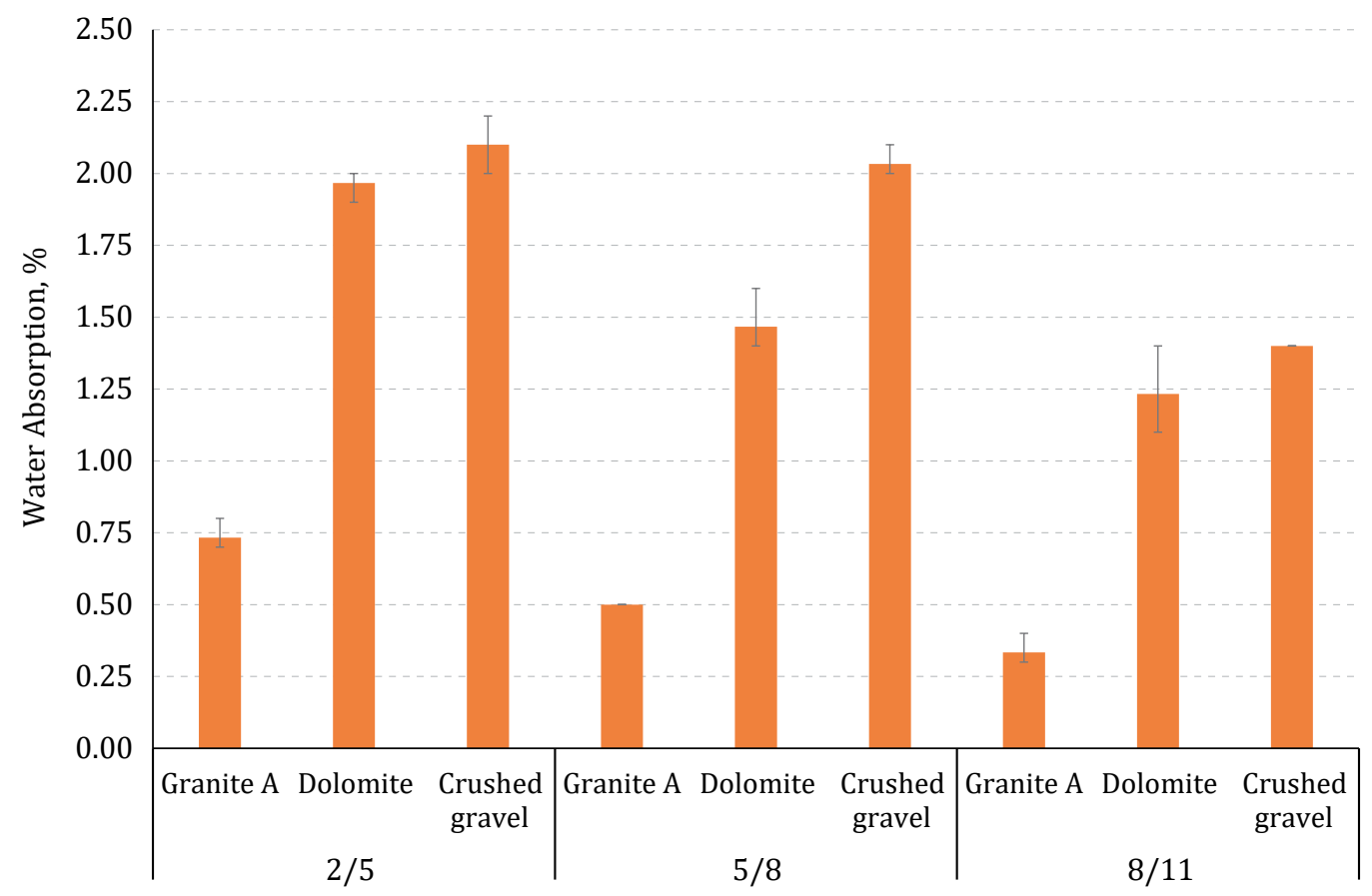

Figure 5. Test results of the water absorption of aggregates 
Crushed and broken surfaces determination test showed that all tested aggregates surfaces are $100 \%$ crushed and broken, except Crushed gravel fraction $8 / 11-99 \%$ of the surface of this material is crushed and broken.

Regarding determined shape characteristics, Granite B and Granite C were rejected from further experimental research, while the bestperformed granite (Granite A) by shape characteristics were tested for resistance to fragmentation (Figure 4) and water absorption (Figure 5).

From the analysis of all results, it is stated that Granite A is the most suitable aggregate for the asphalt mixture of noise-reducing asphalt pavement as water absorption is from $1.3 \%$ to $1.4 \%$ lower than dolomite or crushed gravel.

\subsection{Bituminous binder}

The physical and mechanical properties of the bituminous binder, which were analysed, are presented in Tables 4-6 and Figures 6-15. Error bars in the graphs represent the minimum and maximum values.

All tested unaged bituminous binders met the European standard EN 14023:2010 requirements for penetration, softening point and elastic recovery (Figures 6-8). Moreover, those tests after RTFOT were performed. Test results showed that RTFOT hardens bituminous binder,

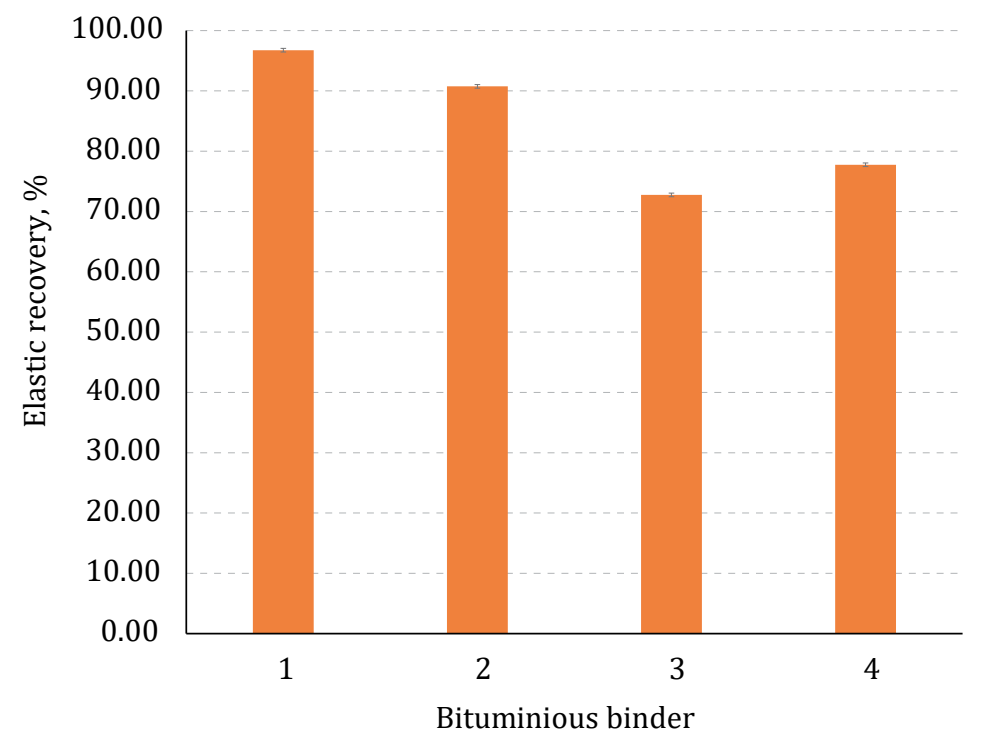

Figure 6. The results of bituminous binder elastic recovery 
but all tested bituminous binders still met retained penetration and increase in softening point requirements by EN 14023:2010.

Elastic recovery test results showed that bituminous binders (1) and (2) are performed better than bituminous binders (3) and (4). Based on results, it is be assumed that the highest amount of polymers was used for bituminous binder (1) manufacturing, while the lowest amount of polymers was used for bituminous binder (3) manufacturing.

Softening point values are given in Figure 7. Bituminous binder (2) showed the best softening point results $\left(68.9^{\circ} \mathrm{C}\right)$. Comparing to all unaged and aged bituminous binder results, was observed that RTFOT increases bituminous binders softening point in the range from $5.2{ }^{\circ} \mathrm{C}$ to $7.1{ }^{\circ} \mathrm{C}$ comparing to unaged bituminous binders. Bituminous binder (2) is the most resistant to RTFOT, while the bituminous binder (3) is the least resistant to RTFOT. Moreover, it was observed, that resistance of bituminous binder to RTFOT depends on the manufacturer.

Penetration values are given in Figure 8. Comparing to all unaged and aged bituminous binder results, was observed that RTFOT decreases the penetration of bituminous binders in the range from $5.6 \mathrm{dmm}$ to $22.2 \mathrm{dmm}$ comparing to unaged bituminous binders. Bituminous binder (1) is the most resistant to RTFOT, while the bituminous binder (2) is the least resistant to RTFOT. Moreover, it was observed that the resistance of bituminous binders to RTFOT depends on the manufacturer.

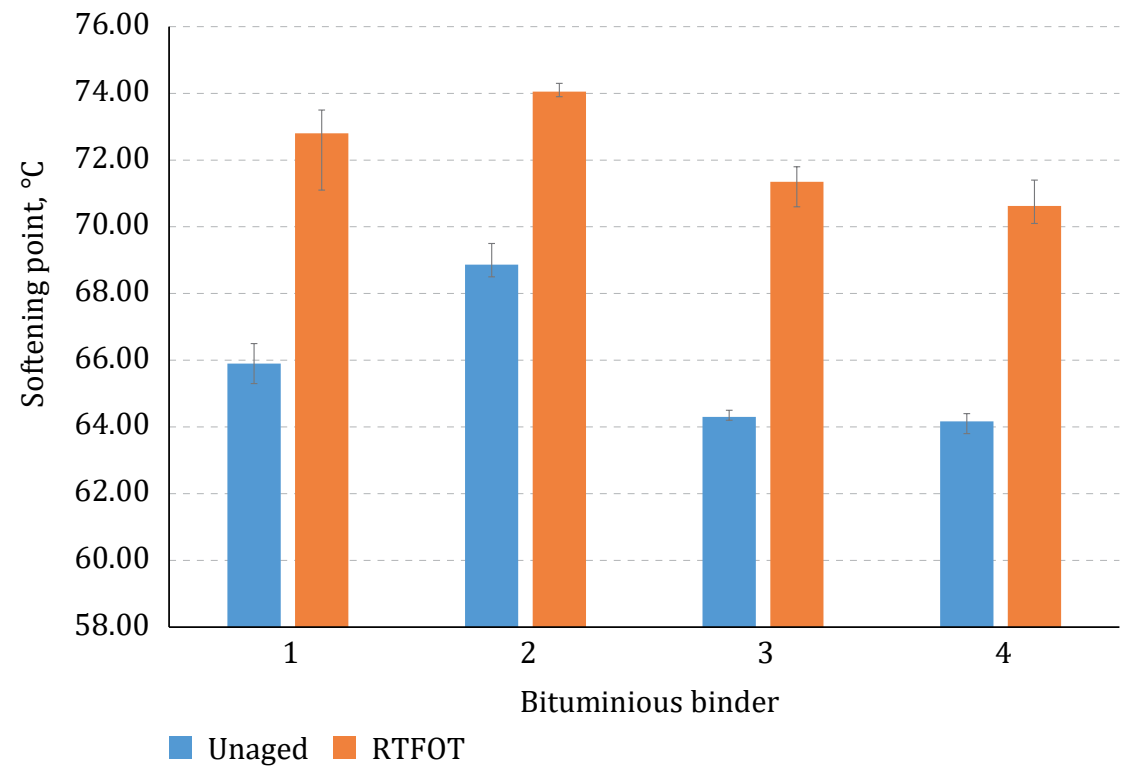

Figure 7. The results of bituminous binder softening point 


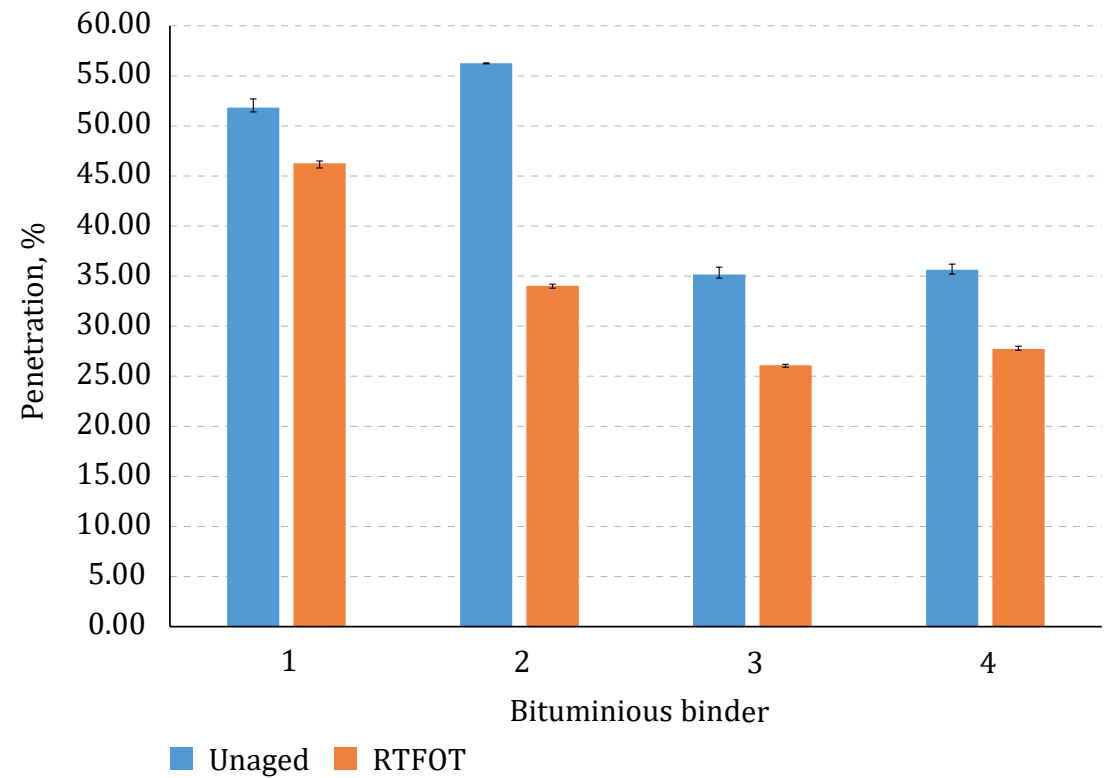

Figure 8 . The results of penetration of bituminous binders

The results of bituminous binder performance at high and low temperatures are shown in Table 4 . The best performance at high temperatures was obtained by a bituminous binder (3), which failed at $86.91{ }^{\circ} \mathrm{C}$ temperature (Figure 9). The lowest performance was obtained by a bituminous binder (2), which failed at $77.39{ }^{\circ} \mathrm{C}$ temperature. Therefore, it is assumed that bituminous binder (3) is the most suitable for high-quality asphalt mixture of noise-reducing asphalt pavement design. However, regarding maximum asphalt pavement temperature

Table 4. The results of bituminous binder performance at high and low temperature

\begin{tabular}{|c|c|c|c|c|c|c|c|c|}
\hline \multirow{3}{*}{$\begin{array}{l}\text { Bituminous } \\
\text { binder }\end{array}$} & \multicolumn{4}{|c|}{ Critical low temperature by } & \multicolumn{4}{|c|}{ Critical temperature } \\
\hline & \multicolumn{2}{|c|}{$G(60)$} & \multicolumn{2}{|c|}{$m_{r}(60)$} & \multicolumn{2}{|c|}{ low } & \multicolumn{2}{|c|}{ high } \\
\hline & ${ }^{\circ} \mathrm{C}$ & Std & ${ }^{\circ} \mathrm{C}$ & Std & ${ }^{\circ} \mathrm{C}$ & Std & ${ }^{\circ} \mathrm{C}$ & Std \\
\hline 1 & -20.8 & 0.471 & -20.5 & 0.141 & -20.5 & 0.125 & 79.71 & 0.029 \\
\hline 2 & -21.5 & 0.236 & -22.0 & 0.125 & -21.5 & 0.236 & 77.39 & 0.102 \\
\hline 3 & -19.5 & 0.424 & -17.4 & 0.698 & -17.4 & 0.698 & 86.91 & 0.431 \\
\hline 4 & -20.5 & 0.216 & -19.1 & 1.575 & -19.0 & 1.517 & 84.53 & 0.131 \\
\hline
\end{tabular}


during the hot season, which is above $50{ }^{\circ} \mathrm{C}$, it is stated, that all tested bituminous binders are considered as suitable for high-quality asphalt mixture of noise-reducing asphalt pavement design in terms of resistance to permanent deformations.

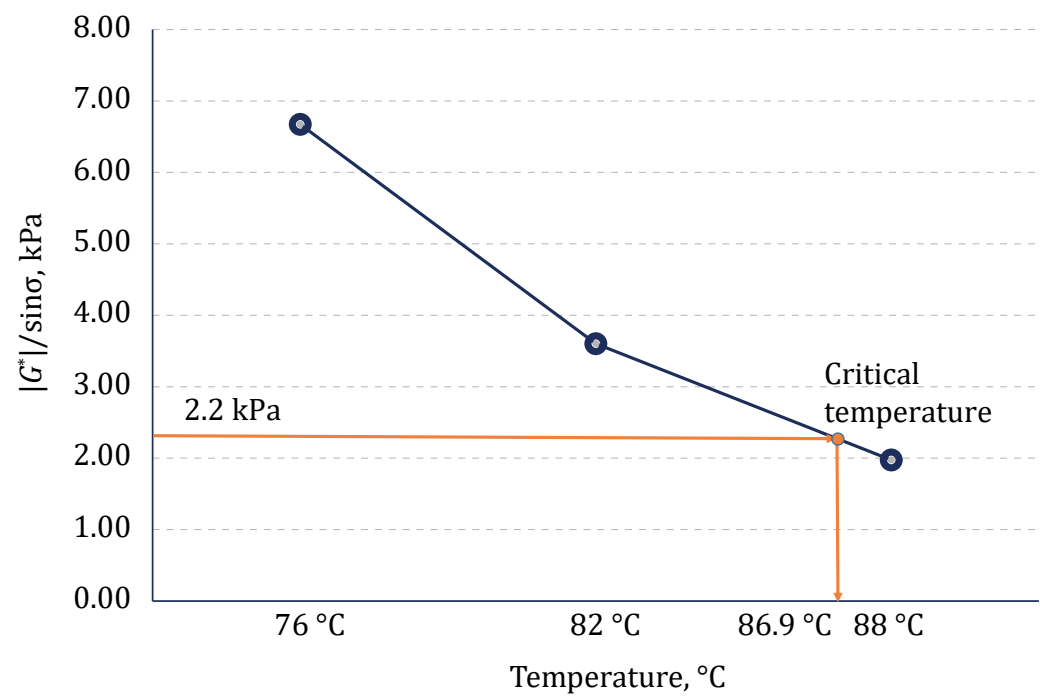

Figure 9. The determination of critical high temperature for bituminous binder (3)

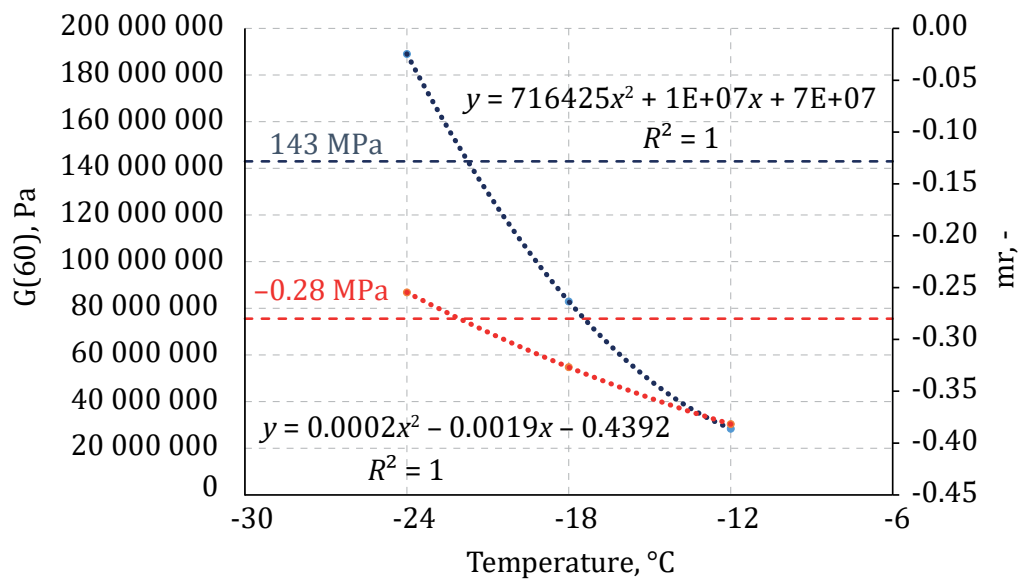

Poly. (Shear modulus) …. Poly. (mr,-)

Figure 10. The determination of critical low temperature for bituminous binder (2)
Selection

of Constituent

Materials

for Asphalt Mixtures

of Noise-Reducing

Asphalt Pavements 
The best performance at low temperatures was obtained by a bituminous binder (2), which failed at $-21.5{ }^{\circ} \mathrm{C}$ temperature (Figure 10). The lowest performance was obtained by bituminous binder (3), which failed at $-17.4{ }^{\circ} \mathrm{C}$ temperature. Therefore, it is be assumed that bituminous binder (2) is the most suitable for high-quality asphalt mixture of noise-reducing asphalt pavement design in terms of resistance to low-temperature cracking. Bituminous binder (1) is also suitable for the design of high-quality asphalt mixture of noise-reducing asphalt pavement in terms of resistance to low-temperature cracking.

The analysis of bituminous binder fractional composition showed that all tested bituminous binders met USA, United Kingdom and Russian recommendations for the asphaltenes (5-25\%). This requirement was met even after RTFOT and RTFOT+PAV. All tested unaged and RTFOT aged bituminous binders contained Russian recommended amount of resins (20-40\%), but the USA and the United Kingdom recommended limiting values were exceeded (15-25\%). After RTFOT+PAV amount of the resins increased and exceeded recommended limiting values. All unaged bituminous binders contained sufficient amount of aromatics, but RTFOT and particularly RTFOT+PAV decreased the amount of aromatics. After RFTOT, only bituminous binder (1) met the requirement for aromatics.

From the analysis of Saturates, Asphaltenes, Resins and Aromatics (SARA) test results, it is stated that unaged bituminous binders meet

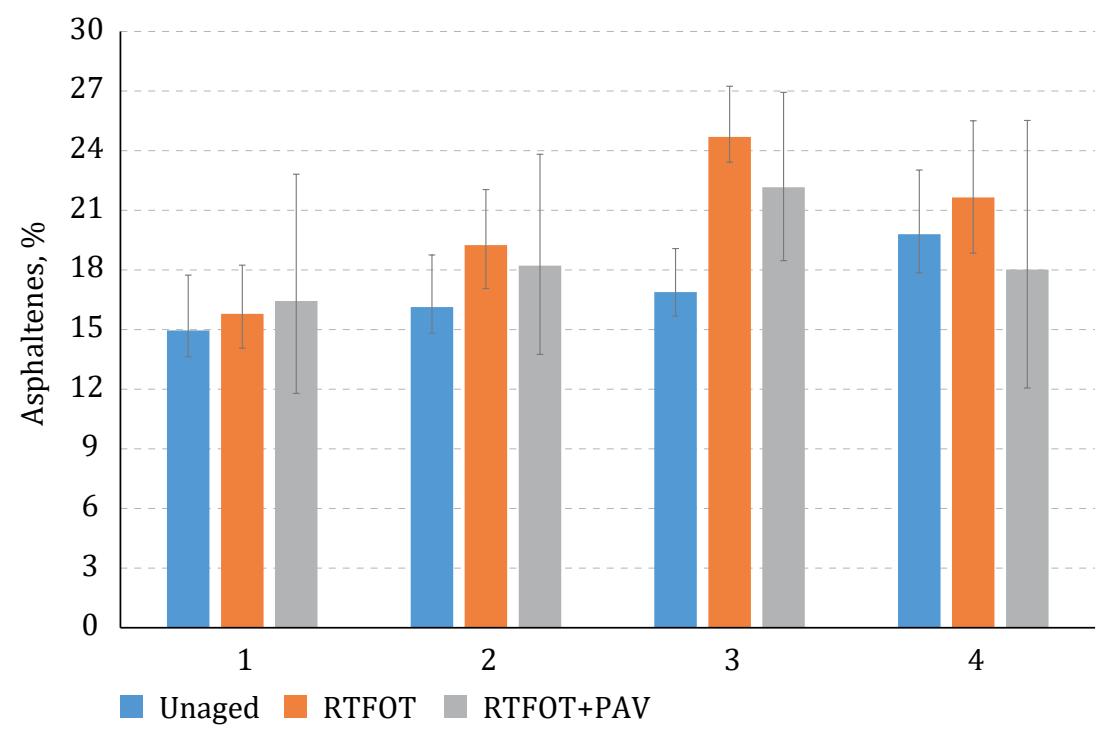

Figure 11. The results of bituminous binder asphaltenes amount 


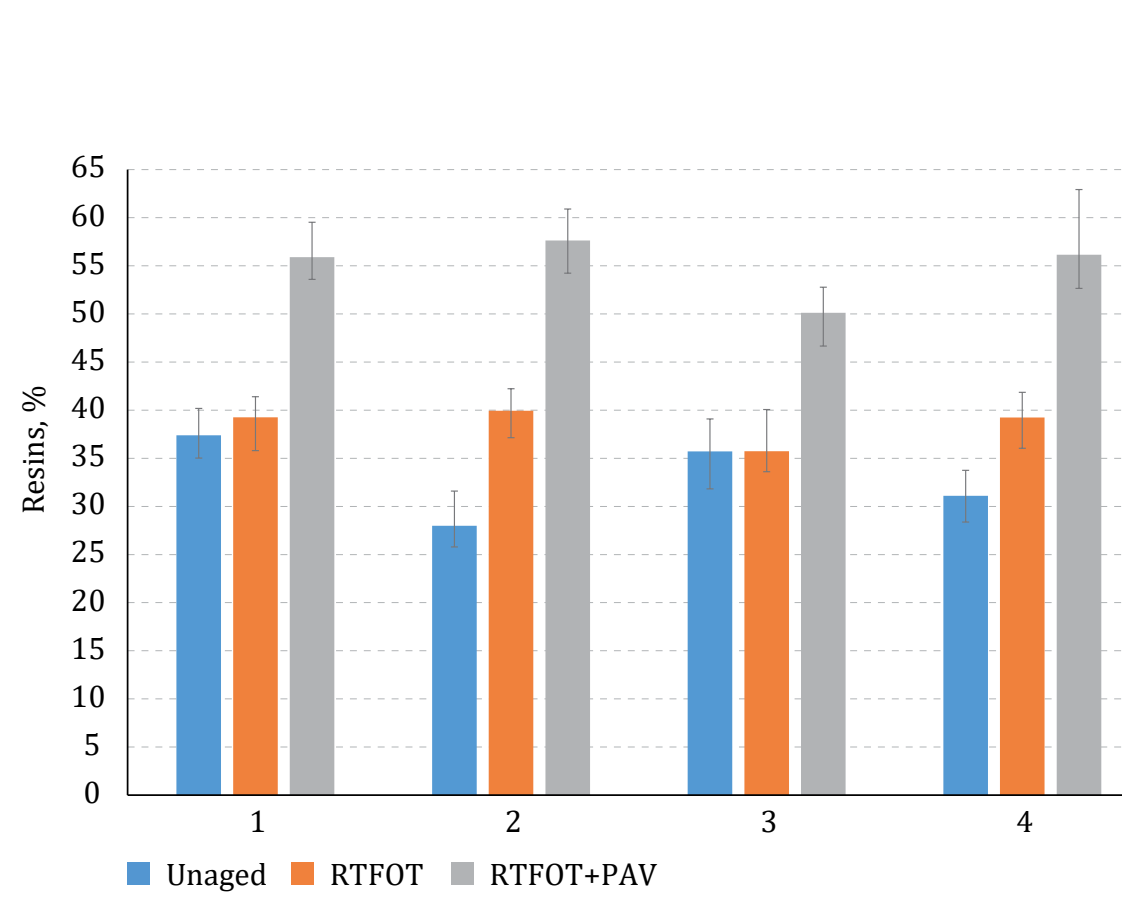

Figure 12. The results of bituminous binder resins amount

recommendations, but short term (RTFOT) and particularly long-term ageing (RTFOT+PAV) decreases the amount of aromatics and increases the amount of resins. It was observed that bituminous binders (2) and (4), produced by one manufacturer, are the most sensitive to ageing.

The analysis of the bituminous binder resistance to fatigue results (Table 5) showed that bituminous binder (2) is the most resistant to fatigue compared to all tested bituminous binders. Bituminous binder (1) showed similar to bituminous binder (2) performance. It is be explained based on SARA test results when was found that both bituminous binders (1) and (2) contains more asphaltenes and fewer resins comparing to bituminous binders (3) and (4). It is be assumed that bituminous binders (1) and (2) are produced using softer neat bitumen comparing to bituminous binders (3) and (4). Polymer-modified bituminous binders produced from softer neat bitumen are more fatigue resistant than bituminous binders produced from harder neat bitumen.

The results of the MSCR test are presented in Table 6 and Figure 15.

Analysis of the MSCR test results showed that RTFOT bituminous binders (2), (3) or (4) are the most resistant to permanent deformation, while RTFOT+PAV bituminous binders (3) and (4) showed the best results. However, differences among results are relatively small, and all tested bituminous binders are to be assumed as resistant to permanent deformation. In Europe, there are no mandatory requirements for
Selection

of Constituent

Materials

for Asphalt Mixtures

of Noise-Reducing

Asphalt Pavements 
Table 5. The results of bituminous binder RTFOT+PAV resistance to fatigue

\begin{tabular}{|c|c|c|c|c|c|c|c|}
\hline $\begin{array}{l}\text { Bituminous } \\
\text { binder } \\
\text { RTFOT+PAV }\end{array}$ & Temperature & $\begin{array}{c}\text { Complex } \\
\text { Shear } \\
\text { Modulus, } \\
\mathbf{G}^{\star}, \mathrm{kPa}\end{array}$ & Std & $\begin{array}{c}\text { Phase } \\
\text { Shift } \\
\text { Angle } \\
\delta_{1^{\circ}}\end{array}$ & Std & $\begin{array}{c}\left|G^{*}\right| \times \sin \delta \\
\mathrm{kPa}\end{array}$ & Std \\
\hline 1 & \multirow{4}{*}{$16^{\circ} \mathrm{C}$} & 19141.5 & 648.9 & 32.20 & 0.31 & 10200.0 & 379.1 \\
\hline 2 & & 16237.5 & 1112.4 & 32.93 & 0.90 & 8821.0 & 519.8 \\
\hline 3 & & 26557.8 & 834.8 & 26.21 & 0.11 & 11730.6 & 380.1 \\
\hline 4 & & 22204.1 & 1111.4 & 28.30 & 0.17 & 10529.6 & 575.2 \\
\hline 1 & \multirow{4}{*}{$19^{\circ} \mathrm{C}$} & 15015.3 & 424.3 & 33.51 & 0.36 & 8290.3 & 268.9 \\
\hline 2 & & 12599.1 & 865.7 & 34.35 & 0.96 & 7102.8 & 396.4 \\
\hline 3 & & 21704.6 & 567.4 & 27.16 & 0.16 & 9907.6 & 297.9 \\
\hline 4 & & 17974.6 & 797.4 & 29.29 & 0.22 & 8794.2 & 440.5 \\
\hline 1 & \multirow{4}{*}{$22^{\circ} \mathrm{C}$} & 11139.1 & 253.3 & 35.19 & 0.44 & 6419.3 & 173.1 \\
\hline 2 & & 9244.8 & 657.5 & 36.11 & 1.01 & 5443.5 & 304.4 \\
\hline 3 & & 16908.4 & 401.3 & 28.42 & 0.19 & 8047.5 & 230.7 \\
\hline 4 & & 13839.1 & 594.4 & 30.59 & 0.23 & 7044.2 & 344.9 \\
\hline 1 & \multirow{4}{*}{$25^{\circ} \mathrm{C}$} & 8035.6 & 138.2 & 36.98 & 0.50 & 4833.4 & 107.0 \\
\hline 2 & & 6581.8 & 465.6 & 37.99 & 1.04 & 4047.6 & 221.9 \\
\hline 3 & & 12889.4 & 254.8 & 29.76 & 0.22 & 6398.2 & 165.1 \\
\hline 4 & & 10412.4 & 406.1 & 31.99 & 0.25 & 5517.4 & 251.9 \\
\hline 1 & \multirow{2}{*}{$28^{\circ} \mathrm{C}$} & 9730.7 & 105.0 & 31.11 & 0.29 & 5027.0 & 82.0 \\
\hline 2 & & 7728.2 & 292.4 & 33.42 & 0.27 & 4257.6 & 190.1 \\
\hline 3 & $31^{\circ} \mathrm{C}$ & 7265.8 & 28.4 & 32.72 & 0.18 & 4333.5 & 578.4 \\
\hline
\end{tabular}

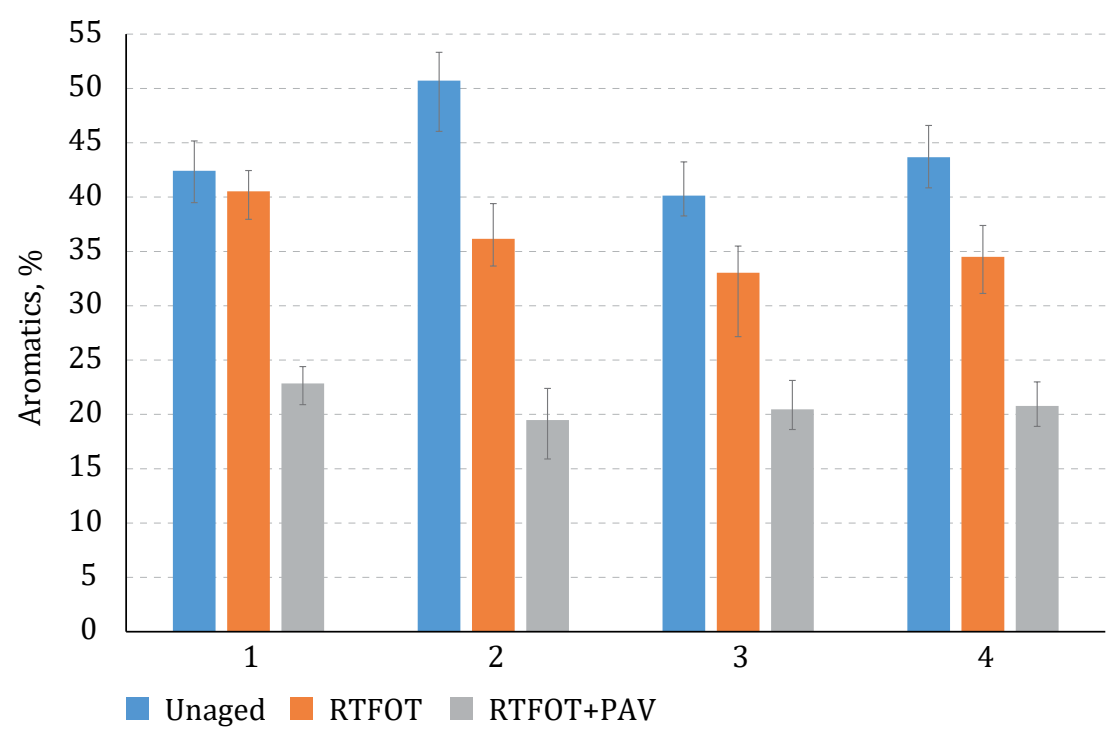

Figure 13. The results of bituminous binder aromatics amount 


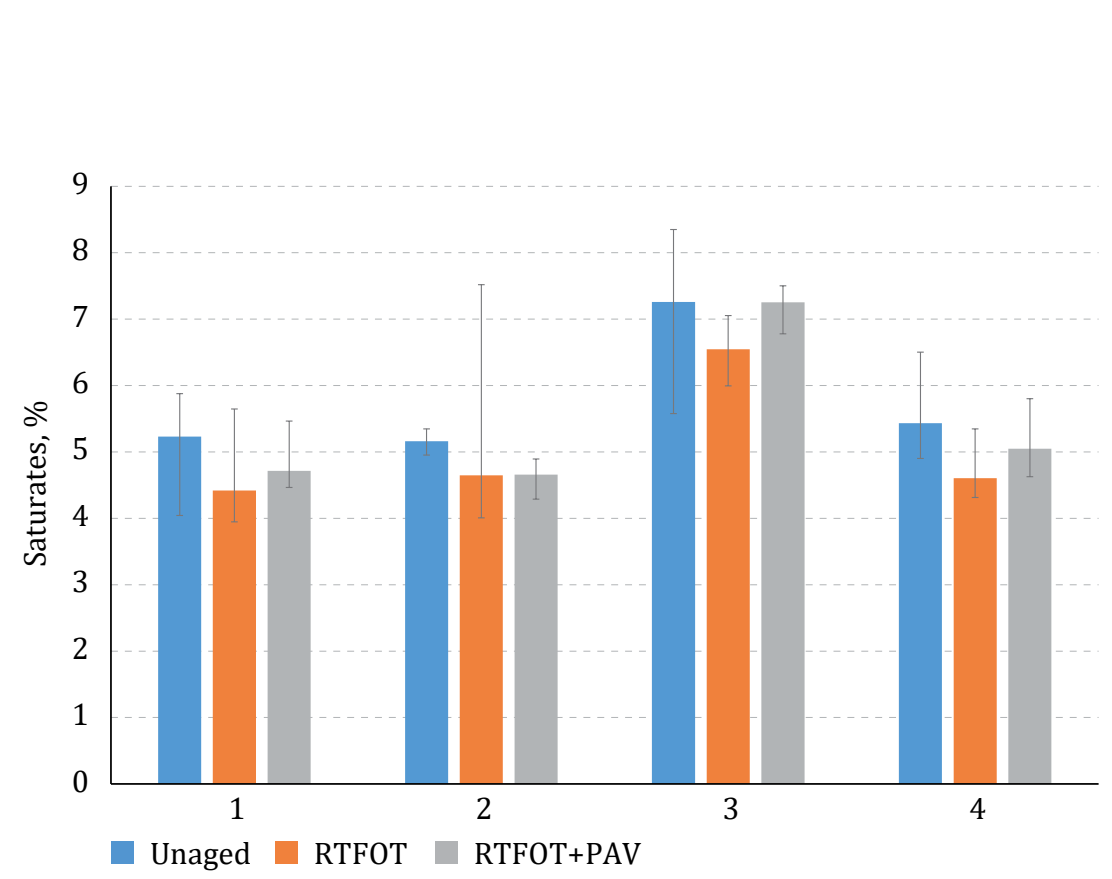

Audrius Vaitkus,

Ovidijus Šernas,

Viktoras Vorobjovas,

Judita Gražulytè

Selection

of Constituent

Materials

for Asphalt Mixtures

of Noise-Reducing

Asphalt Pavements

Figure 14. The results of bituminous binder saturate amount

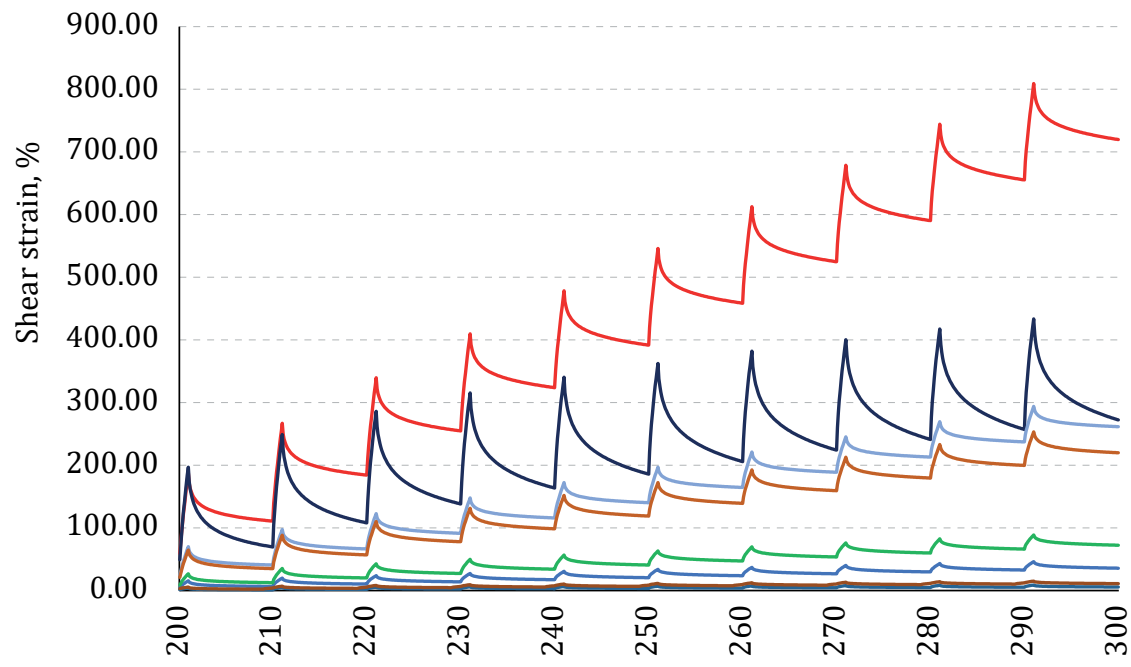

Time, $\mathrm{s}$

$\begin{array}{ll}-1 \text { RTFOT } & -1 \text { RTFOT+PAV } \\ - \text { 2 RTFOT } & -2 \text { RTFOT+PAV } \\ -3 \text { RTFOT } & -3 \text { RTFOT+PAV } \\ -4 \text { RTFOT } & -4 \text { RTFOT+PAV }\end{array}$

Figure 15. Shear strain 
Table 6. The results of the Multiple Stress Creep and Recovery test

\begin{tabular}{|c|c|c|c|c|c|c|c|c|c|c|c|c|c|}
\hline \multirow{2}{*}{ 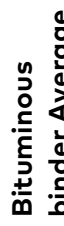 } & & \multicolumn{2}{|c|}{$R_{0.1,} \%$} & \multicolumn{2}{|c|}{$R_{3.2}, \%$} & \multicolumn{2}{|c|}{$\boldsymbol{R}_{\text {diff, }} \%$} & \multicolumn{2}{|c|}{$J_{n r 0.1}, \mathrm{kPa}^{-1}$} & \multicolumn{2}{|c|}{$J_{n r 3.2,}, \mathrm{kPa}^{-1}$} & \multicolumn{2}{|c|}{$J_{\text {nrdiff, }} \mathbf{K P a}^{-1}$} \\
\hline & $\begin{array}{l}\frac{1}{4} \\
\frac{1}{0} \\
0 \\
. \frac{1}{0} \\
\end{array}$ & 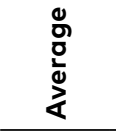 & $\begin{array}{l}\text { Dे } \\
\dot{n}\end{array}$ & 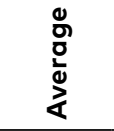 & $\begin{array}{l}\text { Dे } \\
\dot{n}\end{array}$ & 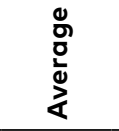 & $\begin{array}{l}\text { Dे } \\
\dot{n}\end{array}$ & 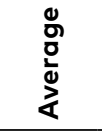 & $\begin{array}{l}\text { Dे } \\
\dot{n}\end{array}$ & $\begin{array}{l}0 \\
\text { ơ } \\
\text { o } \\
\stackrel{0}{\alpha}\end{array}$ & $\begin{array}{l}\text { D } \\
\dot{n}\end{array}$ & 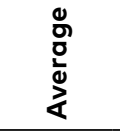 & $\begin{array}{l}\text { Dे } \\
\text { ஸे }\end{array}$ \\
\hline \multirow{4}{*}{$\begin{array}{l}\stackrel{5}{O} \\
\stackrel{\longleftrightarrow}{\leftarrow} \\
\alpha\end{array}$} & 1 & 70.220 & 1.319 & 55.487 & 0.600 & 20.957 & 1.688 & 0.135 & 0.011 & 0.2154 & 0.0084 & 60.463 & 7.263 \\
\hline & 2 & 89.973 & 0.215 & 85.510 & 0.671 & 4.967 & 0.968 & 0.052 & 0.003 & 0.0807 & 0.0012 & 55.057 & 10.253 \\
\hline & 3 & 64.253 & 1.306 & 56.217 & 1.690 & 12.520 & 0.894 & 0.062 & 0.008 & 0.0776 & 0.0097 & 24.613 & 0.999 \\
\hline & 4 & 68.747 & 0.678 & 60.923 & 0.705 & 11.377 & 0.179 & 0.068 & 0.005 & 0.0871 & 0.0062 & 28.480 & 0.322 \\
\hline \multirow{4}{*}{\multicolumn{2}{|c|}{ 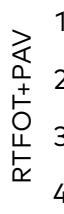 }} & 79.527 & 0.918 & 74.890 & 0.795 & 5.827 & 0.238 & 0.009 & 0.001 & 0.0106 & 0.0013 & 23.710 & 1.830 \\
\hline & & 75.020 & 0.660 & 69.770 & 0.404 & 6.997 & 0.281 & 0.018 & 0.001 & 0.0214 & 0.0008 & 22.293 & 1.828 \\
\hline & & 89.517 & 0.811 & 85.103 & 0.890 & 4.930 & 0.288 & 0.001 & 0.000 & 0.0017 & 0.0003 & 43.493 & 3.345 \\
\hline & 4 & 86.273 & 0.385 & 81.947 & 0.201 & 5.013 & 0.196 & 0.003 & 0.000 & 0.0033 & 0.0001 & 31.890 & 1.294 \\
\hline
\end{tabular}

$J_{n r 3.2}$, but by standard AASHTO M 332:2014, when $J_{n r 3.2}$ is below 0.5 , the bituminous binder is suitable for extreme traffic conditions and is assumed as resistant to permanent deformations in those conditions.

All bituminous binders were ranked considering all tested characteristics results (Table 7). Bituminous binder showed the best

Table 7. Summary of bituminous binders ranking

\begin{tabular}{lrrrr}
\hline \multirow{2}{*}{\multicolumn{1}{c}{ Characteristic }} & \multicolumn{5}{c}{ Bituminous binder } \\
\cline { 2 - 5 } & $\mathbf{1}$ & $\mathbf{2}$ & $\mathbf{3}$ & $\mathbf{4}$ \\
\cline { 2 - 5 } & 4 & 1 & 2 & 3 \\
\hline Retained penetration & 2 & 4 & 1 & 3 \\
Increase in softening point & 4 & 3 & 1 & 2 \\
Elastic recovery & 2 & 1 & 4 & 3 \\
Critical highest temperature & 3 & 4 & 1 & 2 \\
Critical lowest temperature & 2 & 1 & 3 & 4 \\
Non-recoverable creep compliance & 3 & 4 & 1 & 2 \\
Resistance to fatigue & 4 & 1 & 3 & 2 \\
Resistance to hardening & 24 & 19 & 16 & 21 \\
Total & & & \\
\hline
\end{tabular}


result was awarded by score "4", while the bituminous binder showed the lowest result was awarded by score "1".

Summary of bituminous binders ranking results showed that bituminous binder (1) collected the highest score compared to other bituminous binders. It means that bituminous binder (1) in total showed the best characteristics, and is assumed as the most suitable for the design of asphalt mixture for noise-reducing asphalt mixture in terms of resistance to hardening, fatigue, elasticity, permanent deformation and low temperature cracking.

\section{Conclusions and recommendations}

Based on the literature review and the comparative analysis of the different origin aggregates and bituminous binders test results, the following conclusions are drawn:

1. Optimised surface texture and durable performance of noisereducing asphalt pavement wearing course are achieved, selecting aggregate with fully fractured surfaces, resistant to fragmentation, cubic shape, and uniform petrography. Granite A and Dolomite showed the sufficient results of gradation, Flakiness and Shape Indexes (respectively 3-15 and 2-6), water absorption (0.3-2.0) and resistance to fragmentation (Los Angeles coefficient varies from 14.7 to 20.7) comparing to all tested aggregates and met the recommendations for the aggregates of asphalt mixtures for noise-reducing asphalt pavements. Since Granite A showed the best results of Shape Indexes (2-3) and Flakiness Indexes (3-9) comparing to all tested aggregates, this aggregates assumed as the most suitable for the design of asphalt mixture for noisereducing asphalt pavement to achieve highest noise reduction values and durability.

2. Durable performance of noise-reducing asphalt pavement wearing course achievable selecting polymer modified bituminous binders with good elastic properties (elastic recovery is no less than 90\%), resistant to permanent deformation (critical high temperature is no less than $70{ }^{\circ} \mathrm{C}$, non-recoverable creep compliance is below $0.5 \mathrm{kPa}^{-1}$ ) and low-temperature cracking (critical low temperature is no less than $-20{ }^{\circ} \mathrm{C}$ ). The analysis of bitumen fractional composition test results showed that Rolling Thin-Film Oven Test and particularly Pressure Ageing Vessel decreases the amount of aromatics from $44.2 \%$ to $20.9 \%$ and increases the amount of resins from $33.1 \%$ to $55.0 \%$. Furthermore, it was observed that bituminous binders (2) and (4), produced by one manufacturer, 
are more sensitive to ageing comparing to other bituminous binders. The highest critical temperature was obtained by a bituminous binder (3), which failed at $86.91^{\circ} \mathrm{C}$ temperature, while a bituminous binder (2), which failed at $77.39{ }^{\circ} \mathrm{C}$ temperature, obtained the lowest performance. Multiple Stress Creep and Recovery test showed that all tested bituminous binders met the highest requirement of non-recoverable creep compliance by AASHTO M 332:2014 Specification for Performance-graded Asphalt Binder Using Multiple Stress Creep Recovery (MSCR) test (required non-recoverable creep compliance value is no more than $0.5 \mathrm{kPa}^{-1}$ at above 30 million ESALs) - determined values after Rolling ThinFilm Oven Test varied from $0.078 \mathrm{kPa}^{-1}$ to $0.215 \mathrm{kPa}^{-1}$ and after RTFOT+PAV varied from $0.002 \mathrm{kPa}^{-1}$ to $0.021 \mathrm{kPa}^{-1}$. Therefore, all tested bituminous binders are to be assumed as suitable for asphalt mixtures of noise-reducing asphalt pavement design for hot climate regions, where asphalt pavement temperature during hot season rises to $50-60^{\circ} \mathrm{C}$.

3. Bituminous binder (2) showed the best critical low-temperature result (failed at $-21.5{ }^{\circ} \mathrm{C}$ temperature), while the lowest performance was obtained by a bituminous binder (3), which failed at $-17.4{ }^{\circ} \mathrm{C}$ temperature. Both bituminous binders (1) and (2) could be considered as the most resistant to low-temperature cracking. Therefore, these bituminous binders are assumed as the most suitable for high-quality asphalt mixtures of noisereducing asphalt pavement design used for cold climate regions, where asphalt pavement temperature during cold season drops up to $-20^{\circ} \mathrm{C}$.

4. From the analysis of all results, it is stated that Granite A and bituminous binder (1) showed the best results of physical and mechanical properties. Consequently, these materials are assumed as the most suitable materials for the design of the highest quality asphalt mixture of noise-reducing asphalt pavement and will be used for these experimental researches of mixtures.

\section{Acknowledgement}

This project has received funding from the Research Council of Lithuania (LMTLT), agreement No S-MIP-17-137. 


\section{REFERENCES}

AASHTO M 332:2014 Specification for Performance-Graded Asphalt Binder Using Multiple Stress Creep Recovery (MSCR)

AASHTO T 315 Standard Method of Test for Determining the Rheological Properties of Asphalt Binder Using a Dynamic Shear Rheometer (DSR)

AASHTO TP 70 Standard Method of Test for Multiple Stress Creep Recovery (MSCR) Test of Asphalt Binder Using a Dynamic Shear Rheometer (DSR)

AASHTO M 320 Standard Specification for Performance-Graded Asphalt Binder

Alberts, W., O'Malley, V., Byrne, S., Faber, N., \& Roebben, M. (2017). Technical report 2017-01. State of the art in managing road traffic noise: noise reducing pavements. Conference of European Directors of Roads Avenue d'Auderghem 22-28 1040 Brussels, Belgium.

Alvarez, A. E., Martin, A. E., Estakhri, C. K., Button, J. W., Glover, C. J., \& Jung, S. H. (2006). Synthesis of current practice on the design, construction, and maintenance of porous friction courses (No. FHWA/TX-06/0-5262-1).

Anderson, M. (2014). Introduction to the multiple-stress creep-recovery (MSCR) test and its use in the PG binder specification. In 54th Annual Idaho Asphalt Conference.

Andriejauskas, T., Vorobjovas, V., \& Cygas, D. (2016, August). Low noise pavement development for severe climate conditions. In INTER-NOISE and NOISE-CON Congress and Conference Proceedings (Vol. 253, No. 3, pp. 5838-5847). Institute of Noise Control Engineering.

Bendtsen, H., Kragh, J., \& Nielsen, E. (2008). Use of noise reducing pavements European experience. Danish Road Institute, Technical note 69.

Ejsmont, J., Goubert, L., Ronowski, G., \& Świeczko-Żurek, B. (2016). Ultra low noise poroelastic road surfaces. Coatings 6(2): 18. https://doi.org/10.3390/coatings6020018

Ejsmont, J., Świeczko-Żurek, B., Owczarzak, W., Sommer, S., \& Ronowski, G. (2018). Tire/Road Noise on Poroelastic Road Surfaces-Results of Laboratory Measurements, In Proc. of the Euronoise 2018 - the 11th European Congress and Exposition on Noise Control Engineering, Crete, Greece.

EN 12591:2009 Bitumen and Bituminous Binders - Specifications for Paving Grade Bitumens

EN 14023:2010 Bitumen and Bituminous Binders - Specification Framework for Polymer Modified Bitumens

Farrar, M., Sui, C., Salmans, S., \& Qin, Q. (2015). Determining the low temperature rheological properties of asphalt binder using a dynamic shear rheometer (DSR). Technical white paper FP08 prepared by Western Research Institute for the Federal Highway Administration. Contract No. DTFH61-07-D-00005, Fundamental Properties of Asphalts and Modified Asphalts, III.

Hanz, A. (2015). MSCR Implementation and impacts on asphalt binder grading by overview of MSCR implementation, In MAPA Contractors' Workshop Minneapolis, MN, USA.
Selection

of Constituent

Materials

for Asphalt Mixtures

of Noise-Reducing

Asphalt Pavements 
Kim, R. (2007). Burden of disease from environmental noise. In WHO International Workshop on "Combined Environmental Exposure: Noise, Air Pollutants and Chemicals" Ispra.

Kragh, J., Nielsen, E., Olesen, E., Goubert, L., Vansteenkiste, S., \& De Visscher, J. (2011). OPTHINAL Optimization of thin asphalt layers, Era-Net road. Technical report, Road Directorate, Guldalderen 12, 2640 Hedehusene, Denmark.

Li, T., Wen, Y., Feng, H. X., \& Wei, L. (2016). Analysis on the De-noise Effect of Anti-skid Noise Reduction Asphalt Pavement. DEStech Transactions on Engineering and Technology Research, (ictim).

https://doi.org/10.12783/dtetr/ictim2016/5507

LST EN 1097-2:2010 Tests for Mechanical and Physical Properties of Aggregates Part 2: Methods for the Determination of Resistance to Fragmentation

LST EN 1097-6:2013 Tests for Mechanical and Physical Properties of Aggregates Part 6: Determination of Particle Density and Water Absorption

LST EN 13398:2018 Bitumen and Bituminous Binders - Determination of the Elastic Recovery of Modified Bitumen

LST EN 1426:2015 Bitumen and Bituminous Binders - Determination of Needle Penetration

LST EN 1427:2015 Bitumen and Bituminous Binders - Determination of the Softening Point - Ring and Ball Method

LST EN 933-1:2012 Tests for Geometrical Properties of Aggregates - Part 1: Determination of Particle Size Distribution - Sieving Method

LST EN 933-3:2012 Tests for Geometrical Properties of Aggregates - Part 3: Determination of Particle Shape - Flakiness Index

LST EN 933-4:2008 Tests for Geometrical Properties of Aggregates - Part 4: Determination of Particle Shape - Shape Index

LST EN 933-5:2002/A1:2005 Tests for Geometrical Properties of Aggregates - Part 5: Determination of Percentage of Crushed and Broken Surfaces in Coarse Aggregate Particles

McNally, T. (Ed.). (2011). Polymer modified bitumen: Properties and characterisation. Elsevier.

Miljkovic, M. (2012, June). Thin noise-reducing asphalt pavements: towards sustainable transport in urban areas. In Eurasphalt \& Eurobitume Congress, 5th, 2012, Istanbul, Turkey (No. A5EE-211).

Miljković, M., \& Radenberg, M. (2012). Thin noise-reducing asphalt pavements for urban areas in Germany. International Journal of Pavement Engineering 13(6): 569-578. https://doi.org/10.1080/10298436.2011.569028

PIARC Technical Committee (2013). Quiet pavement technologies. ISBN: 978-2-84060-327-6.

Rasmussen, R. O., Bernhard, R. J., Sandberg, U., \& Mun, E. P. (2007). The little book of quieter pavements (No. FHWA-IF-08-004).

Ripke, O., Andersen, B., Bendtsen, H., \& Sandberg, U. (2005). Report of promising new road surfaces for testing. European Commission DG research, Sixth framework programme, Priority 6, Sustainable development, global change \& ecosystems, Integrated project - Contract No. 516288. 
Sakhaeifar, M., Banihashemrad, A., Liao, G., \& Waller, B. (2017). Tyre-pavement interaction noise levels related to pavement surface characteristics. Road Materials and Pavement Design 19(5): 1044-1056. https://doi.org/10.1080/14680629.2017.1287770

Sandberg, U, \& Ejsmont, J. A. (2002).Tyre/Road Noise Reference Book'. Informex HB, Kisa, Sweden.

Sandberg, U., Kragh, J., Goubert, L., Bendtsen, H., Bergiers, A., Biligiri, K. P., Karlsson, R., Nielsen, E., Olesen, E., \& Vansteenkiste, S. (2011). Optimization of thin asphalt layers: state-of-the-art review. Era-Net Road. Deliverable No. 1 - Final version - 30 April 2011 ERA-NET ROAD Project "Optimization of thin asphalt layer".

Snilsberg, B., Myran, T., Uthus, N., \& Aurstad, J. (2008). Evaluation of different laboratory methods for simulation of pavement wear and road dust generation. Road Materials and Pavement Design, 9(sup1), 287-304. https://doi.org/10.1080/14680629.2008.9690170

Syslo, M. (2016). Multiple Stress Creep Recovery (MSCR): New Binder Grade Testing and Terminology Current Superpave Specification. In AASHTO Subcommittee On Materials.

Vaitkus, A., Andriejauskas, T., Gražulytė, J., Šernas, O., Vorobjovas, V., \& Kleizienė, R. (2018, May). Qualitative criteria and thresholds for low noise asphalt mixture design. IOP Conference Series: Materials Science and Engineering (Vol. 356, No. 1, p. 012027). IOP Publishing. https://doi.org/10.1088/1757-899X/356/1/012027

Vorobjovas, V., Šernas, O., Žilionienė, D., Šneideraitienė, L., \& Filotenkovas, V. (2017). Evaluation of high-quality dolomite aggregate for asphalt wearing course. In Environmental Engineering. Proceedings of the International Conference on Environmental Engineering. ICEE (Vol. 10, pp. 1-6). Vilnius Gediminas Technical University, Department of Construction Economics \& Property. : https://doi.org/10.3846/enviro.2017.157

Vuye, C., Bergiers, A., \& Vanhooreweder, B. $(2016)$. The acoustical durability of thin noise reducing asphalt layers. Coatings, 6(2), 21. https://doi.org/10.3390/coatings6020021

Žiliūtė, L., Motiejūnas, A., Kleizienė, R., Gribulis, G., \& Kravcovas, I. (2016). Temperature and moisture variation in pavement structures of the test road. Transportation Research Procedia, 14, 778-786.

https://doi.org/10.1016/j.trpro.2016.05.067
Selection

of Constituent

Materials

for Asphalt Mixtures

of Noise-Reducing

Asphalt Pavements 